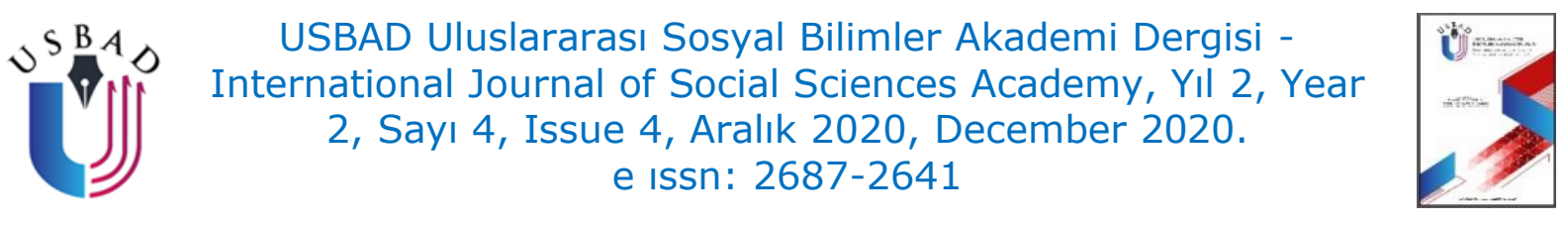

\title{
UYUŞTURUCU MADDE BAĞIMLILIĞINDA AİLENİN ETKİSİ VE BAĞIMLI SAYISININ AZALTILMASINDA JANDARMANIN ETKİNLİĞİ: İSTANBUL'DA BİR UYGULAMA
}

THE EFFECT OF FAMILY IN DRUG ADDICTION AND THE EFFECTIVENESS

OF GENDARMERIE IN REDUCING THE NUMBER OF DEPENDENTS:

A PRACTICE IN ISTANBUL

\author{
Murat KOÇANLI \\ Öğretim Üyesi, Jandarma ve Sahil Güvenlik Akademisi Araştırma Merkezleri \\ Müdürlüğü, Suç Araştırmaları Merkezi Amiri, \\ Ankara/Türkiye. \\ Faculty member, Directorate of Gendarmerie and Coast Guard Academy \\ Research Centers, Supervisor of Crime Research Center, \\ Ankara/Turkey. \\ akadem105@yahoo.com \\ ORCİD ID: $0000-0003-3571-7565$ \\ Makale bilgisi | Article Information \\ Makale Türü / Article Type: Araştırma Makalesi / Research Article \\ Geliş Tarihi / Date Received: 04.07.2020 \\ Kabul Tarihi / Date Accepted: 12.08 .2020 \\ Yayın Tarihi / Date Published: 20.12.2020 \\ Yayın Sezonu / Pub Date Season: Aralık / December
}

Bu Makaleye Atıf İçin / To Cite This Article: Koçanlı, M. (2020). Uyuşturucu Madde Bağımlılığında Ailenin Etkisi ve Bağımlı Sayısının Azaltılmasında Jandarmanın Etkinliği: İstanbul'da Bir Uygulama.

USBAD Uluslararası Sosyal Bilimler Akademi Dergisi 2(4), 576-619.

Intihal: Bu makale intihal.net yazılımınca taranmıştır. İntihal tespit edilmemiştir. Plagiarism: This article has been scanned by intihal.net. No plagiarism detected.

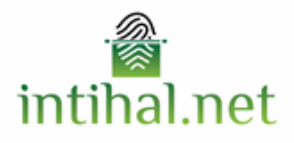

İletişim: Web: https://dergipark.org.tr/tr/pub/usbad mail: usbaddergi@gmail.com 


\section{Murat Koçanlı}

Öz: Günümüzde uyuşturucu madde bağımlılığı ile ilgili tartışmalar gerek yazılı gerekse görsel basında çok sık yer almaya başlamışır. Bunun en önemli nedeni, özellikle henüz 20-25 yaşındaki gençlerin birer birer uyuşturucu madde kullanımından dolayı yaşamlarını kaybetmesidir. Aslında bu tür vakalara Türk toplumunda fazla rastlanılmamaktadır. Nitekim gelişmiş batı toplumlarına göre uyuşturucu madde bağımlı miktarı oldukça düşüktür. Bu araştırmanın amacı, uyuşturucu madde bağımlıı̆ında ailenin etkisini incelemektir. Çalışmanın örneklemi 15-25 yaş aralığında, herhangi bir uyuşturucu madde kullanan ve İstanbul AMATEM'de tedavi almakta olan 103 gençten oluşmaktadır. Uyuşturucu madde bağımlıı̆̆ıın toplumlardan büyük tepki görmesi nedeniyle, bağımlı miktarlarını tespit etmek çok güç olmaktadır. Bu nedenle, uyuşturucu madde bağımlısı olup tedaviye karar veren kitlelere ulaşmak için hastanelerden istifade edilmiştir. Yapılan analiz sonuçlarından; anne-genç ilişkisi, anne-genç arasındaki sorunlar, anne-baba arasındaki geçimsizlik ve ailedeki alkol kullanımının gencin uyuşturucu madde kullanımı üzerinde etkili olduğu saptanmıştır. Bununla birlikte kardeş-genç ilişkisi ile gencin madde tedavi kararı arasında anlamlı bir ilişki olduğu bulgulanmıştır. Buna karşın gençlerin uyuşturucu madde tedavisine karar verme nedeni ile diğer aile değişkenleri arasında anlamlı bir ilişki tespit edilememiştir. Bu veriler doğrultusunda, uyuşturucu madde bağımlılığı ile mücadelede koordinatör görevi bulunan Jandarma Genel Komutanlığına bağımlı sayısının azaltılmasında faydalı olabilecek bazı sosyal önlemler önerilmiştir.

Anahtar Kelimeler: Uyuşturucu, Madde Bağımlılığı, Aile, AMATEM, Jandarma, Gençler

Abstract: Today, the discussions about drug addiction appears very frequently in both the written and visual press. The most important reason for this interest is that young people, especially those 20-25 years old, are losing their lives due to drug use. In fact, such cases are not very common in Turkish society. Indeed, compared to developed Western societies, the amount of drug addicts is quite low. The purpose of this research is to examine the impact of family on drug addiction. The sample of the study consisted of 103 young people aged 15-25 years who used any drugs and were receiving treatment in Istanbul AMATEM. Because drug addiction has a great reaction from the community, it is very difficult to determine the number of addicted invidivuals. For this reason, hospitals were where addicted people were treated utilized to recruit participants. The analysis results suggested thatthe relationship between mother and adolescent, problems between mother and adolescent, conflict between parents and the use of alcohol in the family have an effect on the teen's drug use. However, it was observed that there was a significant relationship between the siblingteen relationship and the teen's substance treatment decision. However, there was no significant relationship between young people's decision on drug treatment and other family variables. Based on the results of this study, to 
enhance the effectiveness of the combat against the drug use, some suggestion were proposed to the Gendarmerie General Command which acts as a coodinator in fight against drug addiction.

Keywords: Drugs, Drug Addiction, Family, AMATEM, Gendarmerie, Youth

\section{GİRIŞ}

Uyuşturucu madde bağımlılığı sadece psikolojik ve biyolojik bir rahatsızlık değildir. Aynı zamanda toplumda meydan getirdiği etkiler düşünüldüğünde disiplinler arası bir sorun olduğu anlaşılır.

Uyuşturucu madde bağımlılığının tek bir nedeni yoktur. Birçok değişken etkili olabilir. Bireylerin kişisel özellikleri, aile yapıları, arkadaş çevreleri ve geçmiş yaşantıları uyuşturucu madde kullanımında etkili faktörlerdir. Bu nedenle uyuşturucu madde bağımlılığının nedenleri araştırılırken disiplinler arası bir yaklaşım kullanılmalıdır.

Toplumu oluşturan en küçük birim ailedir. Aile üyelerinin uyuşturucu madde kullanımı tüm aileyi dolayısıyla toplumun önemli bir kesimini etkilemektedir. Aile ile toplum arasındaki etkileşim karşılıklı olmaktadır.

Türk toplumu gibi gelenek ve göreneklerine bağlı toplumlarda uyuşturucu madde kullanım gibi sapmış davranışlar hoş karşılanmamaktadır. Bu tür davranışlarda bulunan kişilere büyük bir tepki gösterilmektedir. Fakat toplumların hızlı değişmesine paralel olarak, bu tür sapmış davranışların sayısında artış meydana gelmektedir. Bu artışın altındaki temel neden olarak geleneksel aile yapısının değişime uğramaya başlaması söylenebilir.

Bu nedenle çalışmanın esası aile yapılarında yoğunlaşmıştır. Uyuşturucu madde bağımlılığında ailenin etkisini incelemek ve bu doğrultuda kolluk kuvvetlerin alabileceği önleyici kolluk tedbirleri, çalışmanın getireceği en önemli fayda olacaktır.

\section{KAVRAMSAL ÇERÇEVE}

Günümüzde uyuşturucu madde bağımlılığı ile ilgili yapılan araştırmalarda, uyuşturucu madde kullanımın tek bir nedenden kaynaklanmadığı görüşü hakimdir. Uyuşturucu madde bağımlılığı; psikolojide bir kişisel rahatsızlık, biyoloji ve genetik alanında, kalıtımsal bir özellik ve sosyoloji alanında ise toplumsal yapı ile bireylerin kişisel özelliklerinin bir sonucu olarak kabul görmektedir. Bu nedenle uyuşturucu madde bağımlılığını tek bir disiplinle açıklamak mümkün değildir. Bununla birlikte uyuşturucu madde bağımlılığı ile ilgili 
çalışmalar incelendiğinde, yapılan araştırmaların daha çok psikolojik ağırlıklı olduğu görülür. Buna karşın sosyolojik alanlarda yapılan araştırmalar da az değildir. Diğer yandan uyuşturucu madde bağımlılığını biyolojik ve genetik faktörler ile açıklamaya çalışan araştırmalar da mevcuttur. Bu araştırmanın esası sosyolojik bir temele dayandığından, literatür taraması genel olarak sosyolojik alanda yapılmıştır.

Biyolojik ve genetik alanda yapılan araştırmalara göz atıldığında, alkol bağımlılı̆ında rolü ispatlanan genetik özellikler üzerinde yoğunlaştığı görülür. Bu nedenle mevcut ilişkinin uyuşturucu madde bağımlılığına uygulanabilirliğini sınayan araştırmalar yapılmıştır. 2001 yılında Weinberg tarafından yapılan bir araştırmada, aile geçmişinde aile üyelerinin yoğun alkol ve uyuşturucu kullanımının kendi çocuklarının alkol ve uyuşturucu kullanmasına neden olduğu tespit edilmiştir. Söz konusu sonuçlar, Merikangas tarafından 1998'de yapılan araştırma sonuçlarıyla benzerlikler gösterdiği gözlemlenmiştir. Fakat uyuşturucu madde bağımlılığını sadece biyolojik veya genetik özellikler ile açıklamanın yetersiz olacağını savunan araştırmalar da mevcuttur (Newcomb ve Rickards, 1995). Bu araştırmalarda, bu faktörlerinin yanında başka değişkenlerin de etkili olduğu savunulmaktadır.

Uyuşturucu madde bağımlılığı ile ilgili çalışmalar genellikle psikolojik ağırlıklıdır. Araştırmalar genellikle bireylerin kişisel özellikleri, özellikle çocukluk döneminde yaşanan psikolojik travmalar, stresli yaşam tarzı, aile ebeveynlerin psikolojik ilaçlar kullanması ve ebeveynler arasındaki sorunların çatışmaya dönüşmesi üzerinde yoğunlaşmıştır (Miller, 2003). Bu araştırmalara göz atılacak olursa karşımıza ailedeki yoğun sigara, alkol ve uyuşturucu kullanımının bireyleri etkilediği sonucu çıkmaktadır. 1999 yılında Fransa'da 2396 öğrenciye uygulanan bir araştırmada, sigara ve alkol kullanımı olan ailelerin çocukların uyuşturucu madde kullanım riskinin, kontrol grubuna göre on kat fazla olduğu tespit edilmiştir (Challier, 2000). Diğer bir araştırmada ise, Hoffmann tarafından 1998 yılında ABD'de uygulanmıştır. Bu araştırmada da aile ebeveynlerin sigara, alkol ve uyuşturucu kullanımının çocuklar için bir risk faktörü olduğu tespit edilmiştir. Aynı araştırma sonuçlarına göre, aile üyelerinin stresli yaşam tarzı, psikolojik ilaçlar kullanmasının çocukların uyuşturucu madde kullanımı için bir risk faktörü olduğu gözlemlenmiştir.

Bununla birlikte Türkiye'de AMATEM tarafından yapılan araştırmalar da mevcuttur. Bu araştırmalarda az önce ifade edilen 
değişkenler üzerinde durulmuştur. Araştırma sonuçları diğer ülkelerde yapılan araştırma sonuçları ile paralellik göstermektedir $(1996,1998)$.

Aile karakteristikleri ile uyuşturucu madde kullanımı ilişkisini araştıran çalışmalarda, aile yapılanmaları üzerinde durulmuştur. Söz konusu araştırmaları sırayla incelemek gerekir.

Hoffman ve Johnson (2002), yaptığı araştırmada, üvey anne veya babanın olduğu ailelerde, diğer anne ve babası sağ olan ailelere göre çocuklarının uyuşturucu madde kullanımının daha fazla olduğunu tespit etmişlerdir. Bu tür ailelerde aile yapılarındaki sapma davranışlarındaki fazlalığın çocukları uyuşturucu madde kullanımına ittiği gözlemlenmiştir. Aynı araştırmada, sadece annenin olduğu parçalanmış ailelerde çocuklarının uyuşturucu madde kullanım riskinin azaldığı, babanın olduğu ailelerde ise uyuşturucu madde kullanım riskinin yükseldiği saptanmıştır.

Buna karşın Thomas ve Farell (1996) tarafından yapılan araştırmada ise, sadece annenin olduğu parçalanmış aile yapılarında sosyal kontrolün yetersizliğin sapmaya elverişli bir ortam hazırladığı tespit edilmiştir. Bu tür ailelerinin çocuklarında yoğun sigara, alkol ve uyuşturucu kullanımı olduğu gözlemlenmiştir.

Aile yapılarının niteliğindeki sorunların da çocukların uyuşturucu madde kullanımına neden olduğu yapılan araştırmalarda tespit edilmiştir.

Jessor 1977 yılında yaptığı araştırmayla, uyuşturucu madde kullanmaya karşı çocuklarını katı bir şekilde yetiştiren ailelerinin çocukları, inmalkâr yetiştiren ailelerinin çocuklarına göre daha az uyuşturucu madde kullandığını tespit etmiştir. Bu araştırmalarda söz konusu aile yapılarında sosyal kontrolün derecesi, çocuklarının uyuşturucu madde kullanım riskini belirlediği saptanmıştır.

Sampson ve Laub'un yaptığı araştırmada, aile yapısı ile uyuşturucu madde kullanımı arsında bir ilişki olduğunu tespit etmişlerdir. Çalışmalarını Hirschi'nin 1969 yılında geliştirdiği sosyal kontrol teorisine dayandırmışlardır. Çalışmalarında, aile yapılarındaki sorunların, çocukları sapmış davranışlara ve uyuşturucu madde kullanımına ittiğini ileri sürmektedirler. Söz konusu araştırmada, aileye bağılığın kuvvetli olması durumunda uyuşturucu madde kullanım olasılığını en aza indirdiği gözlemlenmiştir.

Katz, Dunham ve Zimmerman'ın (1997) yaptığı araştırmada, aile karakteristikleri ile bireylerin sapma davranışları arasındaki ilişkiyi 
incelemişlerdir. Araştırma sonucunda, aileye bağlılığın derecesi bireyin sapma davranış sıklığını belirlediği gözlemlenmiştir.

2001 yılında yapılan bir çalışmada (Hafsteinsson), aile yönetim biçimleri ile gençlerin uyuşturucu madde kullanımı arasında yakın bir ilişki olduğu tespit edilmiştir. Bu araştırmada, güvene dayanan aile yönetim biçimlerinde, uyuşturucu madde kullanım oranı en düşük düzeyde bulunmuştur. Buna karşın, inmalkâr ve ilgisiz aile yönetim biçimlerinde ise uyuşturucu madde kullanım oranı yüksek bulunmuştur.

Aile-genç iletişimi de uyuşturucu madde kullanımında önemli bir faktör olarak karşımıza çıkmaktadır. Özellikle baba-genç iletişiminin sağlıksız olması, erkek çocuklarının uyuşturucu madde kullanım riskini \%60 oranında artırdığı tespit edilmiştir (Califano, 1999).

Kelly ve arkadaşlarının (2002) yaptığı araştırmada ise, aile içi iletişiminin az olduğu aile yapılarında çocuklarının uyuşturucu madde kullanımın kontrol grubuna göre daha fazla olduğu saptanmıştır.

Bununla birlikte Türkiye'de az sayıda yapılan çalışmalardan söz etmek gerekir. Burcu (2003), yaptığı araştırmada sanayi sitelerinde çalışan bireyler ile aile yapılarındaki sosyal kontrol ilişkisini araştırmıştır. Söz konusu araştırmada, bu tür çocuklarının ailelerinde Sayfa | 581 aile içi ilişkinin sağlıksız olduğu ve aile yapısının sapmaya elverişli bir ortama sahip olduğu gözlemlenmiştir. Dolayısıyla bu tür ailelerin çocukları daha yoğun bir şekilde alkol ve uyuşturucu madde kullanımına başvurmaktadırlar.

Aynı zamanda aile içi ilişkilerinin kötü olması, aile bağlılığının azalmasına neden olmaktadır. Bu durum da gençleri, sapmış arkadaş çevrelerine yönelmesine sebep olmaktadır. Böylece arkadaş çevrelerinde mevcut olan sapmış davranışlar ve uyuşturucu madde kullanımı pekişmektedir (Huba, 1980).

Aile üyelerindeki mevcut olan sigara, alkol ve uyuşturucu kullanımı da çocukların uyuşturucu madde kullanımına neden olmaktadır.

Ailesinde uyuşturucu madde kullanan genç erişkinler, kendi ailelerini örnek alacağından dolayı, uyuşturucu madde kullanımına daha rahat başvurabilmektedirler (Aker, 1979; Hawkins, 1992). Söz konusu araştırmada, sosyal öğrenme kuramı çerçevesinde gençler keskin bir gözlemci olmalarından ötürü uyuşturucu madde kullanımına daha rahat başladıkları tespit edilmiştir. 
Anne veya babanın uyuşturucu madde kullanımı, çocukları üzerindeki gözetim ve denetim etkinliğini azaltır. Dolayısıyla çocukların sapmış davranışlara ve uyuşturucu madde kullanımına başvurması daha rahat olur (Zuckermann, 1991). Böylece sapmış arkadaş gruplarıyla birliktelik sıklığı artmaktadır. Bu tür arkadaş gruplarında, sapmış davranışların öğreniminin pekiştiği gözlemlenmiştir.

Diğer yandan bireylerin okul başarıları ile uyuşturucu madde kullanım ilişkisini araştıran çalışmalar da yapılmıştır.

Okuldaki başarının düşük olması, bireylerin aile yapısına paralel olarak sokak yaşantısına daha fazla bağlı olmasına neden olmaktadır. Bu durum da sapmış davranışlar sergileme olasılığını artırmaktadır (Simpson, 1991).

Okul başarısı, arkadaş gruplarıyla birliktelik ile uyuşturucu madde kullanım ilişkisinin araştırıldığı diğer bir çalışmada, okul başarısı düşük olan çocukların sapmış arkadaş gruplarıyla daha fazla beraber olduğu ve dolayısıyla uyuşturucu madde kullanımın daha yoğun olduğu tespit edilmiştir (Sampson ve Laub, 1993).

Son olarak aile üyelerinin ekonomik seviyeleri ve yaşam ortamlarının aile üyelerinin uyuşturucu madde kullanımına neden Sayfa|582 olduğu çalışmaları incelemek gerekir.

Ekonomik durumu iyi ailelerde çocuklar diğer kontrol gruplarına göre sosyal yaşama az katılmaları nedeniyle, toplumla sosyalizasyon süreçleri sağlıklı olmamaktadır (Downey, 1995). Dolayısıyla söz konusu ailelerde yetersiz gözetim ve denetim, çocuklarının sapmış davranışlara yönelmesine neden olmaktadır.

Buna benzer olarak Coleman 1988 yılında yaptığı araştırmada, ekonomik kazanç yükseldikçe, bireyin toplum ile ilişkisinin artığını ve sosyalizasyon sürecinin sağlıklı gerçekleştiğini tespit etmiştir. Böylece gençlerin sapmış davranışlar ve uyuşturucu madde kullanımı sergileme riski azalmaktadır.

Gençler yaşamlarının ilk yıllarında sosyal, duygusal ve bilişsel gelişimlerini ailelerinin yanında tamamlamaktadırlar. Bu gelişimlerini sorunsuz bir şekilde tamamlayabilmeleri için aile ortamının huzurlu ve sorunsuz olması gerekmektedir. Aksi durumda, gençler duygusal açıdan eksik ve çelişkiler içinde olacaktır (Küçük, 1982'den akt. Arman, 1993). Doğumdan yetişkinlik dönemine kadar gençlerin tutumları, hemen hemen tamamen anne ve baba tarafından şekillendirilmektedir. Bu dönemde gençlerin sapmış davranışlar sergilemesi, aile içinde anne 
ve babanın baskısıyla engellenmektedir. Bu şekilde gençlerin sapmış davranışlar sergileme ve uyuşturucu madde kullanımı riski azaltılmış olmaktadır (Mogan, 1980'den akt. Arman, 1993) Uyuşturucu madde kullanımın ortaya çıkmasında, ailenin gençler üzerindeki etkisinin ve aile ile genç arasındaki ilişkilerin çok önem taşıdığı bilinmektedir. Zira, bu kurumda çıkacak aksaklıklar, kişiliğin oluşumunu tamamen etkileyebilmektedir. Nitekim aile içinde bir bireyin uyuşturucu kullanımı, diğer tüm bireylerin düzenini aksatabilmektedir. Bu nedenle, aile içinde çıkabilecek bir aksaklık sadece o bireyin yaşamının değil tüm aileyi etkileyecektir (Gold, 1993; Robertson, 1994).

Uyuşturucu madde kullanımında, gencin sahip olduğu aile yapısının özelliği çok önemlidir. Bu nedenle mevcut olan aile yapılarının nitelik açısından incelenmesi gerekir. Lamborn'un (1991) belirlediği aile yönetim biçimleri genellikle küçük aile yapılanması şeklindedir. Belirlenen aile yönetim biçimlerinde, aile karakteristikleri ile sapma arasında yakın bir ilişki olduğu saptanmıştır.

Bir ailede var olan huzur ve mutluluk ortamı gençlerin büyümesi ve gelişmesine yardım eder. Bu nedenle ailedeki anne ve baba arasındaki ilişkiler çok önemlidir. Diğer taraftan ailenin kişisel karakteristikleri aile-genç ilişkisini, aile-genç ilişkisi de gençlerin gelişimini ve sapmış davranışlar sergileme olasılığını belirler (Selnow, 1987; Van Voortis, 1988; Brook, 1990). Daha doğrusu gençlerin uyuşturucu madde kullanımı ile aile-genç ilişkisinin kalitesi ile doğrudan ilgilidir (Baumrind, 1991).

Gençler keskin bir gözlemcidir. Aile içindeki ilişkilerin temelini; anne ve baba ilişkileri, bunların birbirine karşı tutumları oluşturur. Bunların sevgi, saygı ve anlayışla sürdürdükleri anne-baba ilişkisi, ailenin genel durumunu belirler. Uyumlu ve sıcak ilişkiler, anne-baba ve genç ilişkisine yansır (İEM, 1999). Anne ve baba arasındaki ilişki, çocuklarına örnek olacak şekilde olmalıdır. Çünkü bireyler, aileleri kendilerine model olarak görürler. Bu çerçevede bireylerin davranışlarını anne ve baba şekillendirir. Buna karşıık anne ve baba arasındaki sorunların büyümesi, gençlerin gelecekte iç çatışmalar yaşaması ve sapmış davranışlar sergilemesine neden olabilmektedir (Yavuzer, 1982).

Aile içinde yaşanan sorunların bir çatışmaya dönüşmesi halinde, gençlerin gelişim çağında olması nedeniyle duygusal bakımdan bir çelişki yaşamaktadırlar. Bu nedenle gençler aile ortamı içinde bulamadıkları huzur ve güveni sokak hayatında arayabilmektedirler. Bu 
durum da gençlerin uyuşturucu madde kullanımı dahil sapmış davranışlar sergileyebilmesine ve hatta suç işleyebilmesine neden olabilmektedir (Hawkins vd., 1992; Hsu, 1993). Bu çatışmanın kızbaba çatışması olması halinde, kız çocukların kendilerini babalara daha yakın hissetmesi nedeniyle bir duygusal boşluk içine düşmektedirler. $\mathrm{Bu}$ boşluk zamanla, uyuşturucu madde kullanımı ile sonuçlanabilmektedir (Brook vd., 1984).

Anne-baba ve genç ilişkisinde önemli olan bir boyut, anne ve babanın alkol ve uyuşturucu kullanımıdır. Anne ve babanın alkol ve uyuşturucu kullanımı, gençlerin sapmış davranışlar sergileyen arkadaş seçimleri ve uyuşturucu madde kullanımında ana etkenlerden biridir. Anne ve babanın alkol veya çeşitli uyuşturucu madde kullanma alışkanlıkları, çeşitli sorunlarla karşılaştıklarında bunları çözmede kullandıkları başa çıkma yolları, ileride gencin de sorunlar ile karşılaştığında, bunlarla başa çıkmak için çeşitli uyuşturucu maddeleri kullanmasında anne ve babayı örnek almasına neden olmaktadır. Ayrıca ailede var olan alkol ve uyuşturucu kullanımı, gençlere uygulanan şiddetin nedenlerinden biridir. Uyuşturucu kullanımı olan ailelerde, kullanımı olmayan ailelere göre daha fazla şiddet olduğu tespit edilmiştir (Bahr vd., 1995; Garett, 1997). Diğer taraftan anne ve Sayfa 584 babası uyuşturucu madde kullanan gençler, davranış ve ruhsal açıdan sorunlu, az sosyalleşmiş ve psikolojik rahatsızlıklar geçirebilmektedir (Sowder, 1980; Johnson, 1991).

Kardeşler arasındaki ilişkiler, gençler üzerinde önemli etki taşımaktadır. Büyük kardeşin küçük kardeş için örnek oluşturma etkisi nedeniyle; uyuşturucu madde kullanan ve madde kullanan arkadaş çevresi olan bir büyük kardeş, küçük kardeş üzerinde olumsuz bir model yaratmaktadır. Bunun yanı sıra, çatışmalı ve olumsuz bir kardeş ilişkisi, bireyin ruhsal uyumu ve huzuru üzerinde bozucu bir etki yaratmaktadır. Dolayısıyla bireyin kardeşi vasıtasıyla uyuşturucu madde ile tanışması daha kolay olabilmektedir (İEM, 1999).

Arkadaş grubu, gençlerin uyuşturucu madde kullanmasında önemli bir faktördür (Güngör, 1999). Nitekim akran ve arkadaş ilişkilerinin gençlerin gelişimi üzerinde önemli etkisi vardır. Gençlik döneminde, akran ilişkileri daha ön plana çıkmakta, akran değer yargı ve davranışları da genç için bir model oluşturmaktadır. Ayrıca birey için, bir akran grubuna ait olma ve grup normları içinde kalma isteği de önemli bir özelliktir. Madde kullanımı, bir grup oluşturan gençler 
arasında, birbirine iletilen bir akran değerler sistemi içinde daha kolay yayılma gösterebilmektedir (Ögel, 1997).

Ailenin sapmış aile modeli olması, çocuğa karşı etkisiz veya dengesiz disiplin veya tutarsız hareketleri, bireyi sapmaya itebilir. Ailegenç arasındaki etkileşimin de bireyi uyum sağlama veya sapma davranışı göstermesini vurgulamaktadır. Aile içi bağlılık yeterli gelişmemişse, birey kendi akranlarıyla daha çok birlikte olur. Akranların seçimi de benzer aile değerleri taşıyan ve davranışlar sergileyen gruplarda olacaktır (Kandel ve Wu, 1995). Bu durum da sapma davranışının pekişmesini sağlar (Patterson, 1992). Ailenin etkisiz disiplin stratejileri, bireyin daha sonra sapma davranışı göstermesinde arttırıcı bir etki göstermektedir (Akers, 1999). Capaldi (1997)'e göre birey, ailesinde uyma davranışına uygun mükafat ve ödül uymama davranışına da tutarlı bir cezalandırma veya görmesi gerektiği tepkiyi görürse uyma eğilimi artacaktır.

Diğer önemli süreçte bireyin akranları ile olan etkileşimidir. Eğer dahil olduğu grup daha çok sapmaya eğilimli bireylerden oluşuyorsa, sapma davranışın öğrenme süreci buna bağlı olarak değişecektir (Steinberg, 1992). Bunun yanında ikincil olarak yakın çevresi komşular, öğretmeni vb. ilişkilerde sapma davranışına yön vermektedir. Özellikle akran grubuyla birliktelik kurulduktan sonra alınan ceza veya pekiştirme gibi unsurlar sonucunda sapma davranışı tecrübe edilerek hem eski tecrübeler hem de yeni tecrübeler eklenerek suç işleme davranışını değiştirmektedir (Akers, 1999). Gençler bu tür arkadaş gruplarında edinilen davranış, tutum, inanç ve tecrübeleri hayatların ilerleyen bölümlerine taşımaktadırlar (Cairns, 1995). Diğer yandan kadınların çoğu uyuşturucu madde kullanımına erkek arkadaşlarının etkisi ve baskısı ile başlamaktadırlar (Amaro, 1995). Uyuşturucu madde kullanıcıları bu tür gruplarda, nasıl uyuşturucu kullanılacağını, uyuşturucunun muhtemelen zarar ve keyiflerini, uyuşturucu kültürü, ulaşımı ve kullanımını öğrenmektedirler (Bachman vd., 1981; Faupel, 1991). Ayrıca bu tür gruplarda, sürekli olarak arkadaşlar arasında geçimsizlikler ve kavgalar yaşanmaktadır. Çünkü bu gruplar genel olarak; dengesiz, zayıf karakterli, çekingen ve çabuk sinirlenen bireylerden oluşmaktadır (Zakharov, 2001).

Okul çağı, bireylerin gruplaşmaya başladığı devredir. Kişinin akran veya oyun gruplarına katılması sosyalleştiğinin önemli bir göstergesidir. Bu devrede, bireyler, hem başkalarının fikir ve davranışlarını idrak etmeye, hem de başkalarının takdirine önem 
vermeye, davranışlarını onların olumlu ve olumsuz tepkilerine göre ayarlamaya başlar (Yavuzer, 1982).

Okul çağından başlayarak, bireyin hayatı boyunca davranışlarını yönlendiren, diğer insanlarla ilişkilerini biçimlendiren temel güdülerden söz edilebilir. Bu güdülerin oluşmasında, ailenin çocuğa karşı davranışları ve tutumları, en önemli faktördür. Çocuğun ileride ne olması gerektiğine, ilk çocukluk yıllarından itibaren ailesi karar verir ve çocuğu yönlendirir. Yani aile açıkça, çocuktan belirli bir şeyler bekler. Böyle bir ortamda büyüyen bireyin davranışlarını ve diğer insanlarla ilişkilerini başarı güdüsü belirleyecektir. Bu bireyin her davranışının ve her ilişkisinin temelinde, gizli de olsa başarılı olma arzusu yer alacaktır (Fişek, 1984). Toplumsal yapının belirlediği başarı hedeflerine ulaşmada başarılı olunamazsa, birey sapma eğilimi gösterecektir (İçli, 2001).

Ergenlik çağı ile birlikte genç, davranış ve kimliğinin oluşumunda kendine bir model arar. Aile çevresindeyken anne-baba veya yakın bir akraba olan bu model, okul çağında öğretmen olmaktadır. Bu haliyle öğretmen, bireyin kimliğinin şekillenmesi ve sosyalleşmesinde en etkili kişilerden biridir. Bu nedenle öğretmen ve okul yöneticilerinin davranışlarında bireylere örnek olmak zorunluluğu vardır. Zira bu sistemde meydana gelecek bir aksama, bireylerin düşük okul başarısı, okula karşı soğukluk hissetmesi ve okul yönetimi ile sorunlar yaşamasına (Yavuzer, 1982), dolayısıyla bireyin okula gitmemesi ve sapmış arkadaş grupları ile beraber olmasına sebep olacaktır (Thornberry, 1987). Diğer taraftan bu aksamalar, bireyin okul yaşantısını yarım bırakması ve sağlıksız gelişimine neden olacaktır (Sampson ve Laub, 1993; Krohn vd., 1997).

Sonuç olarak gençlerin uyuşturucu madde kullanım nedenleri arasında aile karakteristiklerin etkisinin önemi büyüktür. Bu açıklamalar doğrultusunda çalışmanın esasını oluşturan sapma kuramı ile aile karakteristikleri arasında yakın bir ilişki olduğu görülmektedir. Aile ile arkadaş-okul çevresi ve sapma arasındaki yakın ilişki, şekil1'de görülmektedir. Gençlerin aile karakteristiklerinde toplumsal normlara göre sapma ve aile yönetim biçimlerinde yetersiz kontrol veya gözetimdenetim mevcutsa, bireyin içinde yaşadığı sosyal ortam ve bu ortamın yarattığı etkileşim ve sosyal yapı içeriği akran grupları ile benzer özellikler gösteriyorsa, birey bu yapıda mevcut olan sapmış davranışları öğrenerek kendisine bir model oluşturur. Bunun sonucunda bireyler, bulunduğu sosyal yapıya uygun olarak sapma davranışı 
sergilemektedir. Bu açıklamalar doğrultusunda, ailedeki mevcut sapmış davranışların miktarı ve niteliği gençlerin uyuşturucu madde kullanım riskini artırdığı söylenebilir.

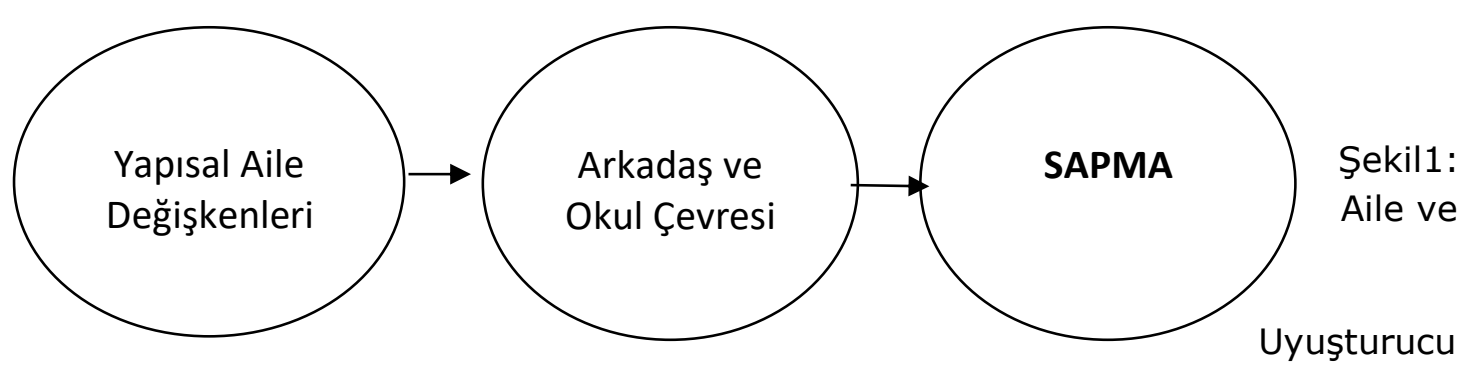

Madde Bağımlılığı İlişkisi (Wade, 1996)

\section{ARAŞTIRMANIN METODOLOJİSi}

\subsection{Konusu}

Uyuşturucu madde bağımlılı̆ı kavramı, son yıllarda gerek yazılı gerekse görsel basında Türkiye'nin gündemine yerleşmiş bir konudur. Bu konuda yapılan çalışmalar incelendiğinde, Türkiye'de sosyoloji alanında psikoloji kadar fazla çalışma yapılmadığı görülür (Ögel, 1995, 1996, 1997; Çakmak, 1996, 1997; Tamar, 1995, 1996, 1997).

Uyuşturucu madde bağımlılarının madde kullanım nedenleri incelendiğinde, arkadaş çevresinin etkisi olduğu kadar aile yapılarından kaynaklanan sorunlarının da madde kullanımında etkili olduğu gözlemlenmektedir (EMCDDA, 2002; UNODC, 2002). Uyuşturucu madde bağımlığının toplumun en küçük sosyolojik birimi olan aile üzerine etkileri toplumun diğer birimlerini de etkileyebilmektedir. Başka bir ifadeyle, toplum ile aile arasındaki etkileşim karşılıklıdır. Zira uyuşturucu madde kullanım nedeni olarak aile etkisinin incelenmesi, toplum düzeni ve değişimi hakkında bir fikir verebilir. Bu nedenle araştırma, 15-25 yaş grubundaki gençlerin uyuşturucu madde bağımlılığında madde kullanım nedeni olarak aile etkisinin olup olmadığını araştırma amacındadır.

\subsection{Araştırmanın Amacı}

Son yıllarda Türkiye'de ve dünyada uyuşturucu madde kullanımında artış olduğu gözlenmektedir. Bununla birlikte madde kullanımının kişi, aile ve toplum üzerinde yarattığı tehlikelere yönelik bir ilgi artışı olmuştur. Gençler, madde kullanımı açısından önemli bir risk grubunu oluşturmaktadır. Gençlik döneminin özellikleri dikkate alındığında, bu dönemde oluşabilecek herhangi bir bağımlılık gençlerin tüm yaşamını etkileyebilecektir. Dolayısıyla, 15-25 yaşları arasındaki 
gençlerin, uyuşturucuya başlama nedenleri arasında kabul edilen aile faktörünün etkisi olup olmadığını incelemek, bu araştırmanın temel amacını oluşturmaktadır.

\subsection{Araştırmanın Yöntemi}

Bu çalışmada karma araştırma metodolojisi uygulanmıştır. İki yöntemin bir arada kullanılmasının en önemli nedeni, konunun derinlemesine ve farklı perspektiflerden incelenmek istenmesidir. Araştırmaya hem kullanıcıların hem de ailelerinin bakış açısını yansıtmak, uyuşturucu madde kullanım nedenlerinin daha iyi anlaşılmasını sağlamıştır.

Bununla birlikte araştırmada betimsel ve analitik çalışma yöntemleri uygulanmıştır. Araştırma grubunun daha önceden uyuşturucu madde kullanıp halen tedavi olan bağımlılar olması nedeniyle grubun sosyo demografik unsurları (cinsiyet, yaş, medeni durum, eğitim düzeyi, kır-kent durumu ve gelir düzeyi), aile yapısı (ailenin eğitim düzeyi, mesleği, sağ ve öz/üvey durumu, aylık gelir seviyesi, sigara, alkol, uyuşturucu madde kullanma ve suç işleme sıklığı), uyuşturucu madde kullanımına başlama faktörleri (madde kullanımının başlangııındaki yaşı ve eğitim düzeyi, madde kullanım nedenleri, madde kullanımında en etkili kimse ve kullanılan ilk madde), uyuşturucu madde kullanımındaki aile içi ilişkilerin niteliği (baba-genç, anne-genç, kardeş-genç ve anne-baba arasındaki ilişkiler), uyuşturucu madde kullanımı (sürekli kullanılan madde ve kullanım süresi, madde temin şekli, madde kullanımından önceki sigara ve alkol kullanma sıklığı ve suç işleme durumu) ve uyuşturucu madde tedavisine karar verme özellikleri (tedavi kararı verildiği anki yaşı ve eğitim düzeyi, tedaviye karar verme nedeni, tedavi kararının verilmesinde en etkili kimse, en son kullanılan madde ve tedaviden sonra geleceğe bakış açısı) betimsel olarak gösterilmiştir.

Analitik çalışma olarak aile yapısı ile gencin uyuşturucu maddeye başlama ve uyuşturucu madde tedavisine karar verme nedeni arasındaki ilişkinin araştırıldığı (2) temel hipotez ve hipotezlerin değişkenlerinin sınandığı (8) alt hipotez test edilmiştir.

Temel Hipotez 1: Aile yapısı ile gençlerin uyuşturucu maddeye başlama nedeni arasında ilişki vardır.

Alt Hipotez 1: Aile içi iletişim ile gencin uyuşturucu maddeye başlama nedeni arasında ilişki vardır. 
- Baba ve gencin birbiriyle olan iletişimi ile gencin uyuşturucu maddeye başlama nedeni arasında ilişki vardır.

- Anne ve gencin birbiriyle olan iletişimi ile gencin uyuşturucu maddeye başlama nedeni arasında ilişki vardır.

- Gencin kardeşleriyle olan iletişimi ile gencin uyuşturucu maddeye başlama nedeni arasında ilişki vardır.

- Anne ve babanın birbiriyle olan iletişimi ile gencin uyuşturucu maddeye başlama nedeni arasında ilişki vardır.

Alt Hipotez 2: Aile ebeveynlerinin yokluğu ve üveyliği ile gencin uyuşturucuya başlama nedeni arasında ilişki vardır.

- Aile ebeveynlerden birinin ya da her ikisinin yokluğu ile gencin uyuşturucu maddeye başlama nedeni arasında ilişki vardır.

- Aile ebeveynlerden birinin ya da her ikisinin üvey olması ile gencin uyuşturucu maddeye başlama nedeni arasında ilişki vardır.

Alt Hipotez 3: Ailenin aylık gelir düzeyi ile gencin uyuşturucuya başlama nedeni arasında ilişki vardır.

Alt Hipotez 4: Ebeveynlerin alkol, sigara ve uyuşturucu madde kullanması ile gencin uyuşturucuya başlama nedeni arasında ilişki Sayfa | 589 vardır.

- Ebeveynlerden birinin ya da her ikisinin alkol kullanması ile gencin uyuşturucu maddeye başlama nedeni arasında ilişki vardır.

- Ebeveynlerden birinin ya da her ikisinin sigara kullanması ile gencin uyuşturucu maddeye başlama nedeni arasında ilişki vardır.

- Ebeveynlerden birinin ya da her ikisinin uyuşturucu madde kullanması gencin uyuşturucu maddeye başlama nedeni arasında ilişki vardır.

Alt Hipotez 5: Ebeveynlerden birinin ya da her ikisinin suç işleme durumu ile gencin uyuşturucu maddeye başlama nedeni arasında ilişki vardır.

Temel Hipotez 2: Aile yapısı ile gençlerin uyuşturucu madde tedavisine karar verme nedeni arasında ilişki vardır.

Alt Hipotez 1: Aile içi iletişim ile gencin uyuşturucu madde tedavisine karar verme nedeni arasında ilişki vardır. 
- Baba ve gencin birbiriyle olan iletişimi ile gencin uyuşturucu madde tedavisine karar verme nedeni arasında ilişki vardır.

- Anne ve gencin birbiriyle olan iletişimi ile gencin uyuşturucu madde tedavisine karar verme nedeni arasında ilişki vardır.

- Gencin kardeşleriyle olan iletişimi ile gencin uyuşturucu madde tedavisine karar verme nedeni arasında ilişki vardır.

- Anne ve babanın birbiriyle olan iletişimi ile gencin uyuşturucu madde tedavisine karar verme nedeni arasında ilişki vardır.

Alt Hipotez 2: Ebeveynlerinin yokluğu ve üveyliği ile gencin uyuşturucu madde tedavisine karar verme nedeni arasında ilişki vardır.

- Ebeveynlerden birinin ya da her ikisinin yokluğu ile gencin uyuşturucu madde tedavisine karar verme nedeni arasında ilişki vardır.

- Ebeveynlerden birinin ya da her ikisinin üvey olması ile gencin uyuşturucu madde tedavisine karar verme nedeni arasında ilişki vardır.

Alt Hipotez 3: Ailenin aylık gelir düzeyi ile gencin uyuşturucu madde tedavisine karar verme nedeni arasında ilişki vardır.

\subsection{Araştırma Grubunun Evreni ve Örneklemi}

Uyuşturucu madde bağımlılığında araştırma yapmak her zaman güçtür. Zira uyuşturucu madde kullanımı, tüm toplumlarda tepki gören bir davranış olarak görülmektedir. Uyuşturucu madde bağımlıları, toplumdan dışlanmamak için kendilerini gizleme eğilimi içerisindedirler. $\mathrm{Bu}$ nedenle, bir toplumda bağımlılara ulaşmak her zaman zor olmaktadır. Uyuşturucu madde bağımlılarına; ceza evi, polis karakolları ve hastaneler gibi merkezlerden ulaşılabilmek mümkündür. Dolayısıyla bu çalışmanın mekânı olarak, uyuşturucu madde bağımlılarının yoğun olarak bulunduğu kabul edilen hastaneler seçilmiştir.

İstanbul merkezinde, uyuşturucu madde bağımlılarına yönelik tedavi merkezi olarak Bakırköy Ruh ve Sinir Hastalıkları Hastanesinde hizmet veren AMATEM merkezi mevcuttur. Bu tedavi merkezinin seçilmesinin nedeni, madde bağımlılığı tedavisi için ayrı bir birimin bulunmasıdır. Ayrıca İstanbul'daki diğer hastaneler (üniversite, SSK, vakıf vb.), madde bağımlılarını tedavi için AMATEM'e sevk etmektedir. Bu nedenle AMATEM, uyuşturucu madde bağımlılığı tedavisinde önemli bir sağlık merkezi olarak değerlendirilmektedir. Dolayısıyla araştırmanın evreni, 15-25 yaş grubunda olan, herhangi bir uyuşturucu madde kullanan ve AMATEM'de tedavi olmaya karar vermiş 


\section{Murat Koçanlı}

bağımlılardan oluşmaktadır. AMATEM'de yapılan incelemede, bu kriterlere uyan 839 bağımlının 01.01.2003-31.12.2003 tarihleri arasında AMATEM'e tedavi olmak amacıyla başvurduğu anlaşılmıştır. Araştırma evren büyüklüğünün 839 ile sınırlı olması nedeniyle, örneklem grubunun evreni temsil edecek sayıda olmasına dikkat edilmiştir.

Dolayısıyla, İstanbul'da uyuşturucu madde tedavi merkezi olarak hizmet veren AMATEM kliniğinde, 15-25 yaşları arasında olan, herhangi bir uyuşturucu maddeyi kullanan ve uyuşturucu madde bağımlısı olarak tedavi gören gençler çalışmanın evrenini (839 bağımlı) ve bu hastaneden rastgele örneklem yoluyla seçilecek olan 103 bağımlı çalışmanın örneklem grubunu oluşturmuştur.

\subsection{Verilerin Değerlendirilmesi ve Analizi}

Uyuşturucu madde bağımlığında aile faktörünün önemini incelemek için hem nicel hem de niteliksel bir çalışma yapılmıştır. İstanbul AMATEM kliniğinden rastgele örneklem yöntemiyle seçilen 103 kişilik örneklem grubuyla, uyuşturucu madde kullanımının aileden kaynaklanan nedenlerini ortaya çıkaran soruların sorulduğu bir anket çalışması yapılmıştır. Anket çalışmasından sonra uyuşturucu madde bağımlılarının aileleri ile derinlemesine görüşme yapılmıştır. Ailelerin sayısının, örneklem grubuyla orantılı olmasına dikkat edilmiştir. Anket ve görüşme esnasında gönüllülük esas kabul edilmiştir. Anket sonuçları, istatistik programı SPSS 10.0 For Windows paket programı, derinlemesine görüşme sonuçları ise, nitel veri değerlendirme teknikleriyle değerlendirilmiştir.

Araştırmaya katılan bireylerin hassas grup olması nedeniyle, 15 Aralık 2004 tarihinde Jandarma Genel Komutanlığı aracılığıyla Bakırköy Ruh ve Sinir Hastalıkları Hastanesinden yazılı izin başvurusunda bulunulmuş ve 15 Ocak 2005 tarihinde gerekli izinler alınmıştır. Bu kapsamda ankete katılan tüm katılımcılara öncellikle araştırmanın amacını ve yöntemini konusunda bilgilendirilmiştir. Rıza formları doldurularak onayı alınmış ve arşivlenmesi sağlanmıştır.

\subsection{Kapsam ve Sınırlılıklar}

Anketin uygulaması safhasında, bazı güçlüklerle karşılaşılmıştır. Özellikle bağımlılarının kolluk kuvvetlerinden çekinmesi nedeniyle, çalışma araştırma görevlisi kimliği ile yapılmıştır. Diğer taraftan, bağımlılarının kullandıkları maddenin özelliğinden dolayı, anket sorularını cevaplandırmada bazı zorluklar yaşadığı tespit edilmiştir. Bu 
aksaklık, anketin bire-bir uygulanmasıyla giderilmiştir. Buna karşılık uçucu madde kullanan bağımlılarının bilinçleri tam açık olmadığından, anketin uygulanması ailelerinin yardımıyla yapılmıştır. Son olarak bağımlılarının kendilerini gizleme eğilimi içerisinde olmalarından ötürü, anket uygulanmasının amaçlarını ayrıntılı bir şekilde sorgulamışlardır.

\section{BULGULARIN TARTIŞILMASI VE ÖNERİLER}

$\mathrm{Bu}$ sonuçlar 15-25 yaş grubundaki herhangi bir uyuşturucu madde kullanan ve AMATEM'de uyuşturucu madde tedavisi olmaya karar vermiş bağımlıları kapsamaktadır. Bulguların, konuyla ilgili genel bir bilgi sağlaması ve başka açılımlara yön verecek nitelik taşıması umulmaktadır. Madde kullanıcıları çok farklı biçimlerde algılanmakta ve tanımlanmaktadır. Bu durum bize kullanıcıların homojen bir grup oluşturmadığını göstermektedir (Ögel, 1997).

Bu araştırmada, araştırma grubunun sosyo demografik özellikleri olarak; cinsiyet, yaş, medeni durum, eğitim düzeyi, kır-kent durumu ve gelir seviyesi esas alınmıştır.

Araştırma grubunun cinsiyet dağılımında kadın bağımlıların oranın \%10 çıkması, diğer çalışma sonuçları ile benzerlikler göstermektedir (EMCDDA, 2002; UNODC, 2002). Araştırma grubunu oluşturan bağımlıların yaş ortalaması 23 yaş civarındadır. Bağımlıların eğitim düzeyi, \%42 oranda ilkokul mezunudur. Medeni duruma bakıldığında grubun \%61'i bekardır. Araştırma grubunun \%89'u yaşamlarının çoğunluğunu kent merkezinde geçirmektedir. Bununla birlikte kent merkezli bir yaşamda bireyin gelir seviyesinin niteliği çok önemlidir. Anket çalışmasına katılan bağımlıların \%23'nün ailelerinin geliri ile yaşamaları, bağımlıların halen herhangi bir meslek sahibi olamamaları ve uyuşturucu maddenin etkisiyle düzensiz bir işleri olmasıyla açıklanabilir.

Ebeveynlerin eğitim düzeyinin çoğunlukla ilkokul mezunudur. Bununla birlikte anne-baba meslekleri incelendiğinde, babalarının genel olarak serbest meslekle uğraştığı görülmüştür. Annelerinin meslekleri ise, çoğunlukla belli bir meslekleri olmadığı ve yaşamlarının çoğunluğunu ev ortamında geçirdikleri gözlemlenmiştir. Bireylerin sorunsuz bir ortamda yetişmesi çok önemlidir. Zira gençlik çağının özellikleri dikkate alındığında anne-baba sevgisinden yoksun kalmaları, gençleri sapmış davranışlara itmesi muhtemeldir. Böyle bir ortamda gençlerin daha kolay uyuşturucu madde kullandığı yapılan 
araştırmalarda ortaya çıkmıştır (Downey, 1995; Hoffman ve Johnson, 1998).

Bu araştırmada, gençlerin aile yapısı ile uyuşturucu madde kullanma ve madde tedavisine karar verme nedeni arasında anlamlı bir ilişki olup olmadığını inceleyen (2) temel hipotez sınanmıştır. Temel hipotezlerdeki değişkenlerin sınanmasını kolaylaştırmak amacıyla (8) alt hipotez ve alt hipotezlerdeki her bir değişken alt problem olarak teşkil edilmiştir.

Bu araştırmada, değişkenler arasındaki anlamlı bir ilişkinin varlığı Ki-Kare (chi-square veya $\chi^{2}$ ) testi kullanılarak sınanmıştır. Bu teknik, iki sınıflamalı değişken arasında anlamlı bir ilişki olup olmadığını test eder. İki değişken arasında bir ilişkinin olması, bir değişkenin düzeylerindeki cevapların diğer değişkenin düzeylerinde farklılaştığını gösterir. Buna göre bu iki değişken arasındaki fark arttıkça, değişkenler arasındaki ilişkinin anlamlı çıkma olasılığı artar (Büyüköztürk, 2002). Bununla birlikte değişkenler arasındaki anlamlı ilişkinin varlığı analiz edilirken 1 'inci tip hata olasılığının \%95 olduğu kabul edilmiştir.

\subsection{1'inci Temel Hipotezin Test Edilmesi}

"Aile yapısı ile gençlerin uyuşturucu maddeye başlama nedeni Sayfa | 593 arasında ilişki vardır."

1 'inci temel hipotezin sınanması amaciyla (5) adet alt hipotez oluşturulmuştur. Her bir alt hipotez kendi içerisinde değerlendirilmiştir. 1 'inci alt hipotezin sınanması için (4) alt problem oluşturulmuştur. Her bir alt problem kendi içerisinde değerlendirilmiştir.

\subsection{1'inci Alt Problemin Test Edilmesi}

"Baba ve gencin birbiriyle olan iletişimi ile gencin uyuşturucu maddeye başlama nedeni arasında ilişki vardır."

Anket çalışmasında, baba-genç iletişimi; iki soruda farklı bir şekilde ölçülmüş olup iki sorudaki değişkenler arasındaki anlamlı bir ilişkinin varlığı ayrı ayrı değerlendirilmiştir. 


\section{Murat Koçanlı}

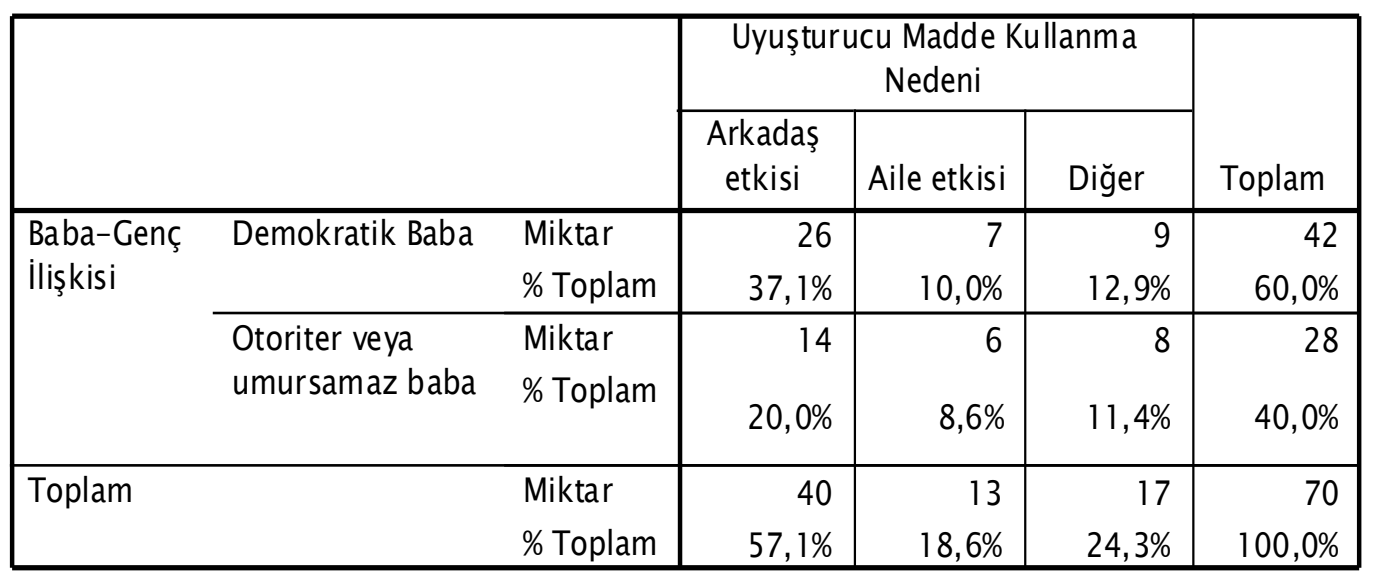

Tablo1: Baba-Genç İlişkisi ile Madde Kullanma Nedeninin

\section{Sınanması}

Babalarıyla olan ilişkisini demokratik olarak niteleyen bağımlıların $\% 37,1^{\prime} i$ arkadaş, \%10'u aile ve \%12,9'u diğer etkilerden (keyif, merak, kişisel bunalım ve okul yaşamı) dolayı uyuşturucu madde kullanımına başlamışlardır. Buna karşın babalarıyla olan ilişkisini otoriter veya umursamaz olarak tanımlayan bağımlıların sadece $\% 8,6$ 'sı uyuşturucu madde kullanım nedeninin aile etkisi olduğunu ifade etmişlerdir. Yapılan analiz sonucu; $\alpha=0.05<p=0,614$ değerleri bulunmuştur. Dolaysıyla bulunan değerin, 0.05 'den büyük olması nedeniyle babagenç ilişkisi ile gencin uyuşturucu madde kullanım nedeni arasında anlamlı bir ilişki olmadığı sonucu çıkmıştır.

\begin{tabular}{|c|c|c|c|c|c|c|}
\hline & \multicolumn{3}{|c|}{$\begin{array}{l}\text { Uyuşturucu Madde Kullanma } \\
\text { Nedeni }\end{array}$} & \multirow[b]{2}{*}{ Toplam } \\
\hline & & & $\begin{array}{l}\text { Arkadaş } \\
\text { etkisi }\end{array}$ & Aile etkisi & Diğer & \\
\hline \multirow{4}{*}{$\begin{array}{l}\text { Baba ve Genç } \\
\text { Arasındaki Sorunlar }\end{array}$} & \multirow[t]{2}{*}{ Sorunlar vardı } & Miktar & 17 & 9 & 6 & 32 \\
\hline & & \% Toplam & $24,3 \%$ & $12,9 \%$ & $8,6 \%$ & $45,7 \%$ \\
\hline & \multirow[t]{2}{*}{ Sorunlar yoktu } & Miktar & 23 & 4 & 11 & 38 \\
\hline & & \% Toplam & $32,9 \%$ & $5,7 \%$ & $15,7 \%$ & $54,3 \%$ \\
\hline \multirow[t]{2}{*}{ Toplam } & & Miktar & 40 & 13 & 17 & 70 \\
\hline & & \% Toplam & $57,1 \%$ & $18,6 \%$ & $24,3 \%$ & $100,0 \%$ \\
\hline
\end{tabular}

Tablo2: Baba ve Genç Arasındaki Sorunlar ile Madde Kullanma Nedeninin Sınanması

Baba-genç iletişimini ölçen diğer soruda, baba ve genç arasındaki sorunlar ile uyuşturucu madde kullanım nedeni arasındaki ilişki araştırılmıştır. Babalarıyla arasında sorunların olduğunu belirten bağımlıların \%24,3'ü arkadaş, $\% 12,9$ 'u aile ve $\% 8,6$ 'sı diğer 


\section{Murat Koçanlı}

nedenlerden ötürü uyuşturucu madde kullanımına başlamışlardır. Fakat babalarıyla arasında herhangi bir sorun olmadığını belirten bağımlıların sadece \%5,7'si uyuşturucu madde kullanım nedeni olarak görmektedir. Yapılan analiz sonucu; $\alpha=0.05<p=0,149$ değerleri bulunmuştur. Bu nedenle, baba ve genç arasındaki sorunlar ile gencin uyuşturucu madde kullanım nedeni arasında anlamlı bir ilişki yoktur.

\subsection{2'nci Alt Problemin Test Edilmesi}

"Anne ve gencin birbiriyle olan iletişimi ile gencin uyuşturucu maddeye başlama nedeni arasında ilişki vardır."

Anne-genç iletişimi de baba-genç iletişimi gibi iki soruda ölçülmüş olup, değişkenler arasındaki anlamlı bir iliş̧kinin varlığı ayrı ayrı değerlendirilmiştir.

\begin{tabular}{|c|c|c|c|c|c|c|}
\hline & \multicolumn{3}{|c|}{$\begin{array}{l}\text { Uyuşturucu Madde Kullanma } \\
\text { Nedeni }\end{array}$} & \multirow[b]{2}{*}{ Toplam } \\
\hline & & & $\begin{array}{l}\text { Arkadaş } \\
\text { etkisi }\end{array}$ & Aile etkisi & Diğer & \\
\hline \multirow{4}{*}{$\begin{array}{l}\text { Anne-Cenç } \\
\text { İlişkisi }\end{array}$} & \multirow[t]{2}{*}{ Demokratik Anne } & Miktar & 42 & 8 & 14 & 64 \\
\hline & & \% Toplam & $46,7 \%$ & $8,9 \%$ & $15,6 \%$ & $71,1 \%$ \\
\hline & \multirow{2}{*}{$\begin{array}{l}\text { Otoriter veya } \\
\text { umursamaz anne }\end{array}$} & Miktar & 9 & 8 & 9 & 26 \\
\hline & & \% Toplam & $10,0 \%$ & $8,9 \%$ & $10,0 \%$ & $28,9 \%$ \\
\hline \multirow[t]{2}{*}{ Toplam } & & Miktar & 51 & 16 & 23 & 90 \\
\hline & & \% Toplam & $56,7 \%$ & $17,8 \%$ & $25,6 \%$ & $100,0 \%$ \\
\hline
\end{tabular}

Tablo3: Anne-Genç İlişkisi ile Madde Kullanma Nedeninin Sınanması

Tablo3 incelendiğinde, anneleriyle olan ilişkisini demokratik olarak tanımlayan bağımlıların sadece $\% 8,9$ 'u uyuşturucu madde kullanım nedenin aile olduğu görülür. Diğer taraftan anneleriyle olan ilişkisini otoriter veya umursamaz olarak nitelendiren bağımlıların uyuşturucu madde kullanım nedenin oranı da \%8,9 olarak saptanmıştır. Anne-genç ilişkisi ile uyuşturucu madde kullanım nedeni arasındaki ilişkiyi test etmek amacıyla yapılan analiz sonucu; $\alpha=0.05>p=0,020$ değerleri tespit edilmiştir. Dolayısıyla anne-genç ilişkisi ile gencin uyuşturucu madde kullanım nedeni arasında anlamlı bir ilişki olduğu söylenebilir. Bununla birlikte iki değişken arasındaki anlamlı ilişkinin derecesini tespit etmek amacıyla yapılan Cramer's $\mathrm{V}$ testin sonucunda, iki değişken arasındaki ilişkinin \%29,4 oranında olduğu saptanmıştır. 


\section{Murat Koçanlı}

\begin{tabular}{|lll|r|r|r|r|}
\hline & & \multicolumn{3}{|c|}{ Uyuşturucu Madde Kullanma } & \\
\cline { 3 - 6 } & & \multicolumn{2}{|c|}{ Nedeni } & \\
\cline { 3 - 6 } & & Arkadaş & & \\
& & etkisi & Aile etkisi & Diğer & Toplam \\
\hline Anne ve Genç & Sorunlar vardı & Miktar & 8 & 10 & 5 & 23 \\
Arasındaki Sorunlar & & \% Toplam & $8,9 \%$ & $11,1 \%$ & $5,6 \%$ & $25,6 \%$ \\
\cline { 2 - 6 } & Sorunlar yoktu & Miktar & 43 & 6 & 18 & 67 \\
& & \% Toplam & $47,8 \%$ & $6,7 \%$ & $20,0 \%$ & $74,4 \%$ \\
\hline Toplam & Miktar & 51 & 16 & 23 & 90 \\
& & \% Toplam & $56,7 \%$ & $17,8 \%$ & $25,6 \%$ & $100,0 \%$ \\
\hline
\end{tabular}

Tablo4: Anne ve Genç Arasındaki Sorunlar ile Madde Kullanma Nedeninin Sınanması

Tablo4, annesi ile arasında sorunların olduğunu belirten bağımlıların \%11,1'i aile etkisinden ötürü uyuşturucu madde kullandığını göstermektedir. Buna karşın annesi ile arasında herhangi bir sorun olmadığını belirten bağımlıların \%47,8'i uyuşturucu madde kullanımına arkadaş çevresinin etkisiyle başlamışlardır. Yapılan analiz sonucu; $\alpha=0.05>p=0,001$ değerlerinin çıkması nedeniyle, anne ve genç arasındaki sorunlar ile gencin uyuşturucu madde kullanım nedeni arasında anlamlı bir ilişkinin varlığı saptanmıştır. Ayrıca iki değişken arasındaki ilişkinin \%39,8 oranında olduğu gözlemlenmiştir.

\subsection{3 'üncü Alt Problemin Test Edilmesi}

"Gencin kardeşleriyle olan iletişimi ile gencin uyuşturucu maddeye başlama nedeni arasında ilişki vardır." Bu alt problemdeki anlamlı ilişkinin varlığı tek soruda ölçülmüştür.

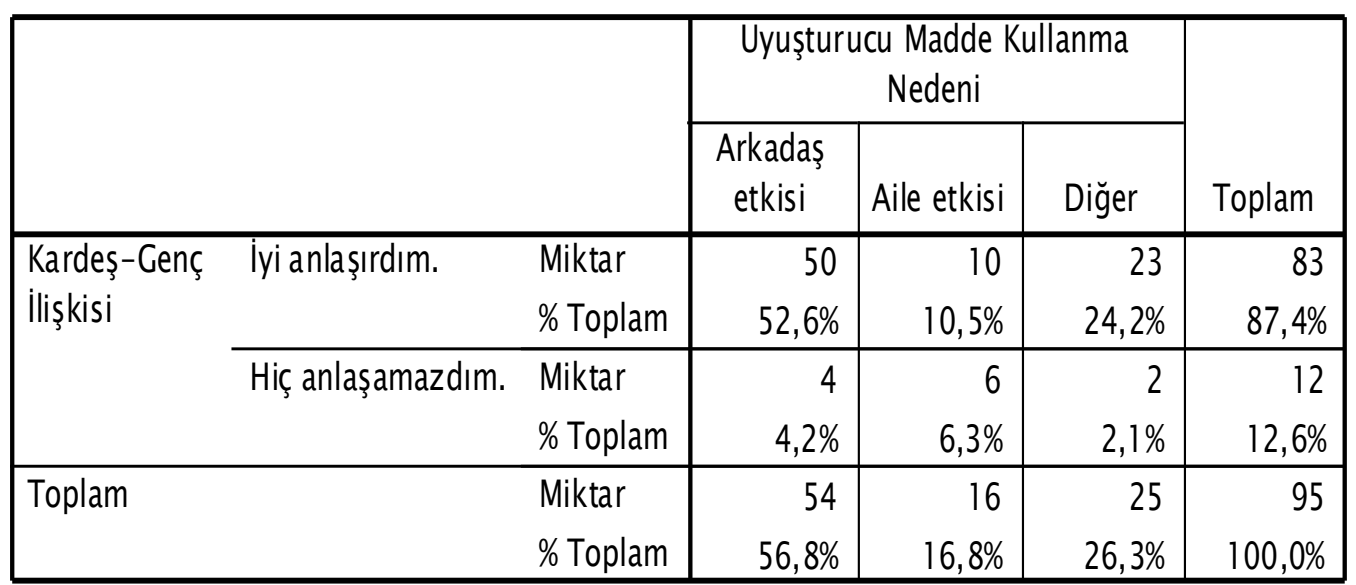

Tablo5: Kardeş-Genç İlişkisi ile Madde Kullanma Nedeninin Sınanması 


\section{Murat Koçanlı}

Yapılan analiz sonucu, gözelerdeki 5'ten küçük iki gözün teorik değeri \%33,3 olarak tespit edildiğinden, kardeş-genç ilişkisi ile gencin uyuşturucu madde kullanım nedeni arasındaki anlamlı bir ilişkinin varlığı Ki-Kare yöntemiyle saptanmaz. Bu durumda yüzde dağılımına bakıldığında, kardeşleriyle anlaşamayan bağımlıların sadece \%6,3'ü aile etkisinden dolayı uyuşturucu madde kullanımına başladıkları görülür. Buna karşın, kardeşleriyle genel olarak iyi anlaşan bağımlıların $\% 52,6$ 'sı arkadaş, \%10,5'i aile ve \%24,2'si diğer nedenlerden ötürü uyuşturucu madde kullanımına başlamışlardır.

\subsection{4'üncü Alt Problemin Test Edilmesi}

"Anne ve babanın birbiriyle olan iletişimi ile gencin uyuşturucu maddeye başlama nedeni arasında ilişki vardır."

Anne ve baba arasındaki iletişim üç soruda ölçülmüş olup, değişkenler arasındaki anlamlı bir ilişkinin varlığı ayrı ayrı değerlendirilmiştir.

\begin{tabular}{|c|c|c|c|c|c|c|}
\hline & \multicolumn{3}{|c|}{$\begin{array}{l}\text { Uyuşturucu Madde Kullanma } \\
\text { Nedeni }\end{array}$} & \multirow[b]{2}{*}{ Toplam } \\
\hline & & & $\begin{array}{l}\text { Arkadaş } \\
\text { etkisi }\end{array}$ & Aile etkisi & Diğer & \\
\hline \multirow{4}{*}{$\begin{array}{l}\text { Anne ve Baba } \\
\text { Arasındaki Anlaşma }\end{array}$} & \multirow[t]{2}{*}{ Anlaşırlardı } & Miktar & 30 & 9 & 12 & 51 \\
\hline & & \% Toplam & $43,5 \%$ & $13,0 \%$ & $17,4 \%$ & $73,9 \%$ \\
\hline & \multirow[t]{2}{*}{ Anlaşamazlardı } & Miktar & 9 & 4 & 5 & 18 \\
\hline & & \% Toplam & $13,0 \%$ & $5,8 \%$ & $7,2 \%$ & $26,1 \%$ \\
\hline \multirow[t]{2}{*}{ Toplam } & & Miktar & 39 & 13 & 17 & 69 \\
\hline & & \% Toplam & $56,5 \%$ & $18,8 \%$ & $24,6 \%$ & $100,0 \%$ \\
\hline
\end{tabular}

Tablo6: Anne ve Baba Arasındaki Anlaşma ile Madde Kullanma Nedeninin Sınanması

Anne ve baba arasındaki anlaşma ile gencin uyuşturucu madde kullanım nedeni arasındaki ilişki yüzde dağııımı ile incelendiği zaman, anne ve babası arasında herhangi bir sorun olduğunu belirten bağımlıların sadece \%5,8'i aile etkisinden dolayı uyuşturucu madde kullanımına başladıkları görülür. Bu oran, arkadaş çevresi etkisinin yaklaşık yarısı kadardır. Başka bir ifadeyle aile etki oranı oldukça düşük olduğu gözlemlenmiştir. 


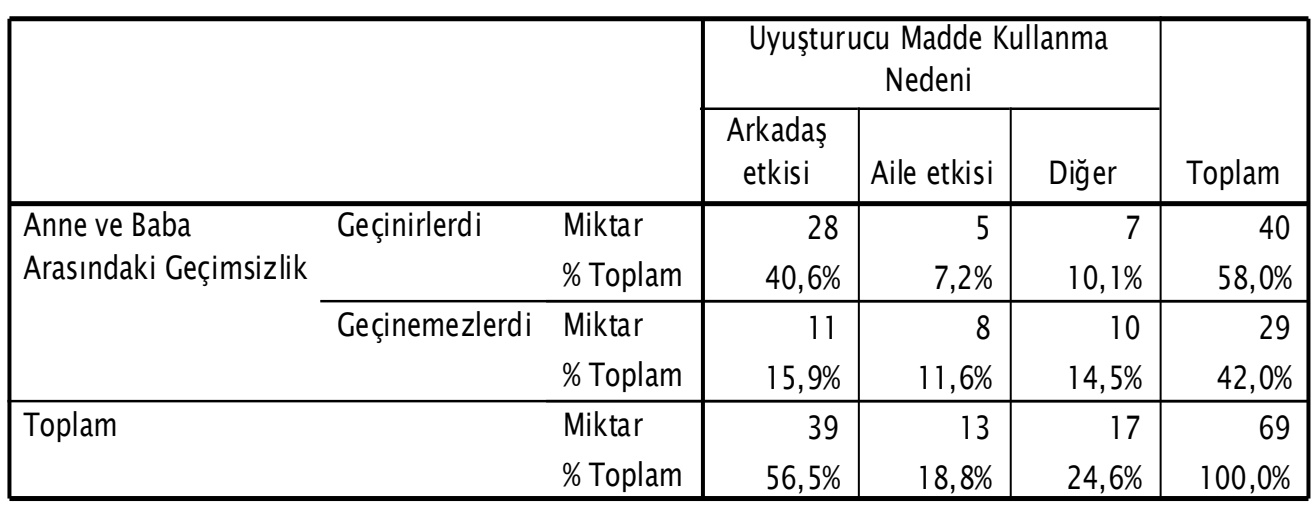

Tablo7: Anne ve Baba Arasındaki Geçimsizlik ile Madde Kullanma Nedeninin Sınanması

Anne ve baba arasındaki geçimsizliğin ölçüldüğü soruda, bağımlıların \%11,6'sı aile etkisinden ötürü uyuşturucu madde kullanmaya başladıkları gözlemlenmiştir. Buna karşın anne ve babası arasında herhangi bir geçimsizliği olmadığını belirten bağımlıların $\% 40,6$ 'sı arkadaş etkisiyle uyuşturucu madde kullanımına başladığı tespit edilmiştir. Yapılan analiz sonucu; $\alpha=0.05>p=0,029$ değerleri saptandığından, anne ve baba arasındaki geçimsizlik ile gencin uyuşturucu madde kullanım nedeni arasında anlamlı bir ilişki olduğu gözlemlenmiştir

\begin{tabular}{|lll|r|r|r|r|}
\hline & & \multicolumn{3}{|c|}{ Uyuşturucu Madde Kullanma } & \\
\cline { 3 - 6 } & & \multicolumn{2}{|c|}{$\begin{array}{c}\text { Arkadaş } \\
\text { etkisi }\end{array}$} & Aile etkisi & Diğer & \multirow{2}{*}{ Toplam } \\
\hline Babanın Anneye Şiddet & Uygulardı & Miktar & 12 & 2 & 1 & 15 \\
Uygulaması & & \% Toplam & $17,4 \%$ & $2,9 \%$ & $1,4 \%$ & $21,7 \%$ \\
\cline { 3 - 6 } & Uygulamazdı & Miktar & 27 & 11 & 16 & 54 \\
& & \% Toplam & $39,1 \%$ & $15,9 \%$ & $23,2 \%$ & $78,3 \%$ \\
\hline Toplam & Miktar & 39 & 13 & 17 & 69 \\
& & \% Toplam & $56,5 \%$ & $18,8 \%$ & $24,6 \%$ & $100,0 \%$ \\
\hline
\end{tabular}

Tablo8: Babanın Anneye Şiddet Uygulaması ile Madde Kullanma Nedeninin Sınanması

Babanın anneye şiddet uygulaması anlaşma ile gencin uyuşturucu madde kullanım nedeni arasındaki ilişki yüzde dağılımı ile incelendiğinde, babasının annesine şiddet uyguladığını belirten bağımlıların \%2,9'u aile etkisiyle uyuşturucu madde kullanımına başladıkları görülür. Arkadaş etkisiyle uyuşturucu madde kullanımına başlayanların oranın \%17,4 olarak tespit edilmesi, babanın anneye 


\section{Murat Koçanlı}

şiddet uygulaması değişkeninde arkadaş çevresinin önemini ortaya koymaktadır.

Genel olarak 1'inci alt hipotez sınandığında; sadece anne-genç iletişimi ve anne ve baba arasındaki geçimsizlik ile gencin uyuşturucu madde kullanma nedeni arasında anlamlı bir ilişki olduğu tespit edilmiştir. Diğer değişkenler ile gencin uyuşturucu madde kullanma nedeni arasında istatiksel olarak anlamlı bir fark saptanamamıştır.

\subsection{2'nci Alt Hipotezin Test Edilmesi}

"Aile ebeveynlerinin yokluğu ve üveyliği ile gencin uyuşturucuya başlama nedeni arasında ilişki vardır." Bu alt hipotez iki alt problem olarak değerlendirilmiştir.

\subsection{1'inci Alt Problemin Test Edilmesi}

"Aile ebeveynlerden birinin ya da her ikisinin yokluğu ile gencin uyuşturucu maddeye başlama nedeni arasında ilişki vardır." Bu alt problemdeki anlamlı ilişki tek soruda sınanmıştır.

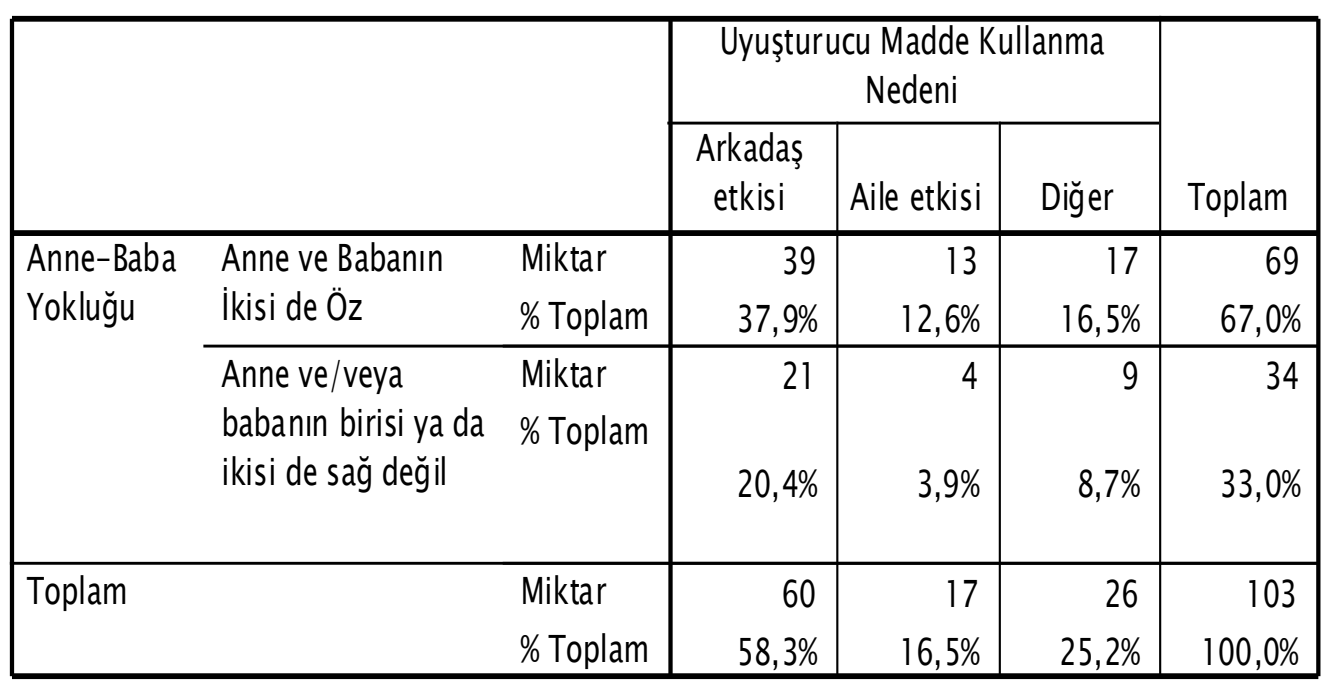

Tablo9: Anne-Baba Yokluğu ile Madde Kullanma Nedeninin Sınanması

Anne ve/veya babası ya da her ikisi sağ olmayan bağımlıların sadece \%3,9'u aile etkisiyle uyuşturucu madde kullanımına başlamışlardır. Buna karşın arkadaş etkisiyle uyuşturucu madde kullananların oranı, \%20,4 olduğu tespit edilmiştir. Yapılan analiz sonucu; $\alpha=0.05<p=0,661$ değerleri bulunmuştur. Bu nedenle, annebaba yokluğu ile gencin uyuşturucu madde kullanım nedeni arasında anlamlı bir ilişki yoktur. 


\section{Murat Koçanlı}

\subsection{2'nci Alt Problemin Test Edilmesi}

"Aile ebeveynlerden birinin ya da her ikisinin üvey olması ile gencin uyuşturucu maddeye başlama nedeni arasında ilişki vardır." Bu alt problemdeki anlamlı ilişki tek soruda sınanmıştır.

\begin{tabular}{|c|c|c|c|c|c|c|}
\hline & & & \multicolumn{3}{|c|}{$\begin{array}{l}\text { Uyuşturucu Madde Kullanma } \\
\text { Nedeni }\end{array}$} & \multirow[b]{2}{*}{ Toplam } \\
\hline & & & $\begin{array}{l}\text { Arkadaş } \\
\text { etkisi }\end{array}$ & Aile etkisi & Diğer & \\
\hline \multirow{3}{*}{$\begin{array}{l}\text { Anne-Baba } \\
\text { Üveyliği }\end{array}$} & \multirow{2}{*}{$\begin{array}{l}\text { Anne ve Babanın } \\
\text { İkisi de Öz }\end{array}$} & Miktar & 56 & 16 & 25 & 97 \\
\hline & & $\%$ Toplam & $54,4 \%$ & $15,5 \%$ & $24,3 \%$ & $94,2 \%$ \\
\hline & $\begin{array}{l}\text { Anne ve/veya } \\
\text { babanın birisi ya da } \\
\text { her ikisi de üvey }\end{array}$ & $\begin{array}{l}\text { Miktar } \\
\text { \% Toplam }\end{array}$ & $3,9 \%$ & $1,0 \%$ & $1,0 \%$ & $5,8 \%$ \\
\hline \multirow[t]{2}{*}{ Toplam } & & Miktar & 60 & 17 & 26 & 103 \\
\hline & & \% Toplam & $58,3 \%$ & $16,5 \%$ & $25,2 \%$ & $100,0 \%$ \\
\hline
\end{tabular}

Tablo10: Anne-Baba Üveyliği ile Madde Kullanma Nedeninin Sınanması

Anne-baba üveyliğinin yüzde dağılımı incelendiğinde, bağımlıların sadece \%1'i aile etkisiyle uyuşturucu madde kullanımına başladıkları görülür. Diğer taraftan anne ve babası sağ olan bağımlıların Sayfa | 600 $\% 15,5^{\prime}$ i aile etkisiyle uyuşturucu madde kullanımına başlamışlardır. Bu oranın oldukça düşük olması, anne-baba üveyliğinin gencin uyuşturucu madde kullanımında etkili olmadığı söylenebilir.

2'nci alt hipotez analiz edildiğinde, anne-baba yokluğu ve üveyliği ile gencin uyuşturucu madde kullanım nedeni arasında anlamlı bir ilişki tespit edilemediği görülür.

\subsection{3'üncü Alt Hipotezin Test Edilmesi}

"Ailenin aylık gelir düzeyi ile gencin uyuşturucuya başlama nedeni arasında ilişki vardır." Bu alt hipotez tek alt problem olarak değerlendirilmiştir. 


\section{Murat Koçanlı}

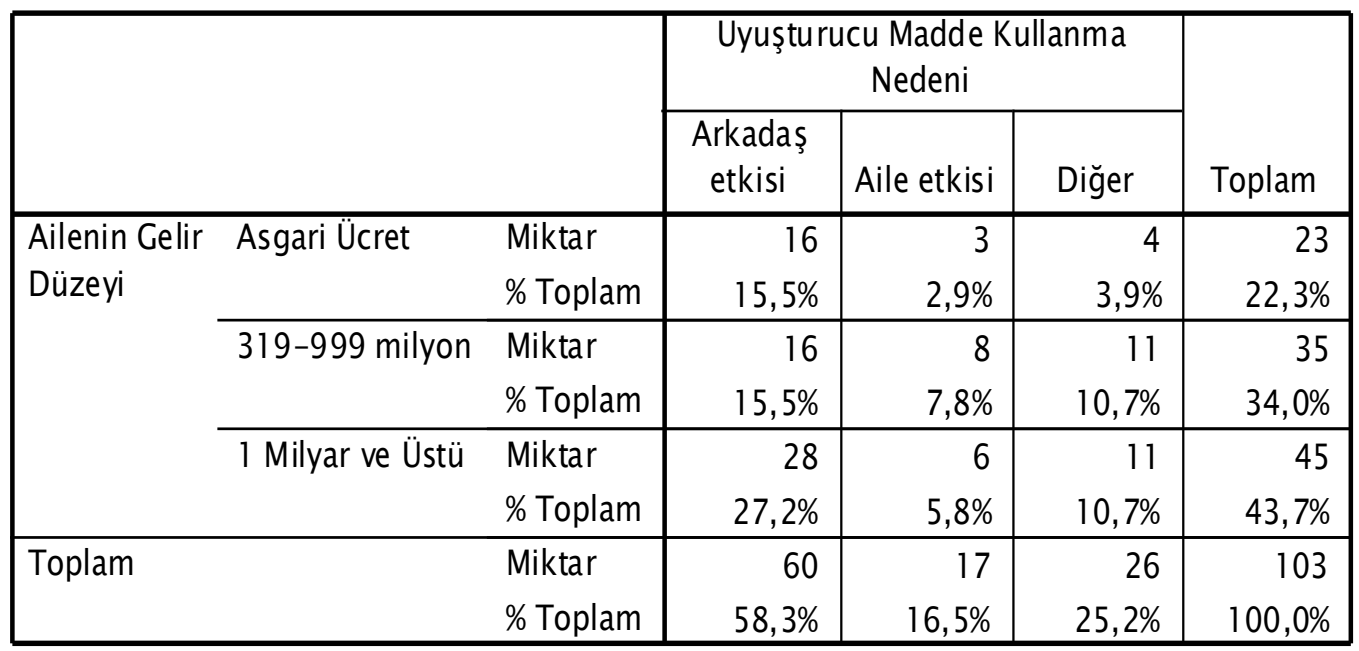

Tablo11: Aile Gelir Düzeyi ile Madde Kullanma Nedeninin Sınanması

Araştırma grubun \%43,7'si ailelerin ortalama aylık gelir seviyesinin 1 milyar ve üstünde olduğunu ifade etmişlerdir. Bu oran aynı zamanda grubun herhangi bir maddi sorun yaşamadığının göstergesidir. Fakat bu oran içindeki ailenin etkisiyle uyuşturucu madde kullanan bağımlıların oranın oldukça düşük olduğu tespit edilmiştir. Aile gelir düzeyi ile gencin uyuşturucu madde kullanım nedeni arasında anlamlı bir ilişki olmadığı yapılan analiz sonucu; $\alpha=0.05<p=0,410$ değerlerinin saptanmasıyla tespit edilmiştir.

\subsection{4'üncü Alt Hipotezin Test Edilmesi}

"Ebeveynlerin alkol, sigara ve uyuşturucu madde kullanması ile gencin uyuşturucuya başlama nedeni arasında ilişki vardır." Bu alt hipotez üç alt problem olarak değerlendirilmiştir.

\subsection{1'inci Alt Problemin Test Edilmesi}

"Ebeveynlerden birinin ya da her ikisinin alkol kullanması ile gencin uyuşturucu maddeye başlama nedeni arasında ilişki vardır." Bu alt problemdeki anlamlı ilişki tek soruda sınanmıştır. 


\section{Murat Koçanlı}

\begin{tabular}{|c|c|c|c|c|c|c|}
\hline & \multicolumn{3}{|c|}{$\begin{array}{l}\text { Uyuşturucu Madde Kullanma } \\
\text { Nedeni }\end{array}$} & \multirow[b]{2}{*}{ Toplam } \\
\hline & & & $\begin{array}{l}\text { Arkadaş } \\
\text { etkisi }\end{array}$ & Aile etkisi & Diğer & \\
\hline \multirow{4}{*}{$\begin{array}{l}\text { Ailede } \\
\text { Alkol } \\
\text { Kullanımı }\end{array}$} & $\begin{array}{l}\text { Aile üyelerinden } \\
\text { herhanai biri alkol }\end{array}$ & & 13 & 10 & 6 & 29 \\
\hline & kullanıyor & \% Toplam & $12,6 \%$ & $9,7 \%$ & $5,8 \%$ & $28,2 \%$ \\
\hline & Aile üyelerinden hiçbiri & Miktar & 47 & 7 & 20 & 74 \\
\hline & alkol kullanmıyor & \% Toplam & $45,6 \%$ & $6,8 \%$ & $19,4 \%$ & $71,8 \%$ \\
\hline \multirow[t]{2}{*}{ Miktar } & & Miktar & 60 & 17 & 26 & 103 \\
\hline & & \% Toplam & $58,3 \%$ & $16,5 \%$ & $25,2 \%$ & $100,0 \%$ \\
\hline
\end{tabular}

Tablo12: Ailede Alkol Kullanımı ile Madde Kullanma Nedeninin Sınanması

Ailede herhangi birinin alkol kullanan bağımlıların \%12,6'sı arkadaş, \%9,7'si aile ve \%5,8'i diğer nedenlerin etkisi ile uyuşturucu madde kullanımına başlamışlardır. Yapılan analiz sonucu; $\alpha=0.05>p=0,009$ değerlerinin tespit edilmesinden ötürü, ailede alkol kullanımı ile gencin uyuşturucu madde kullanımı arasında istatiksel olarak bir fark olduğu söylenebilir. Ayrıca iki değişken arasındaki ilişkinin \%30,3 oranında olduğu tespit edilmiştir.

\subsection{2'nci Alt Problemin Test Edilmesi}

"Ebeveynlerden birinin ya da her ikisinin sigara kullanması ile gencin uyuşturucu maddeye başlama nedeni arasında ilişki vardır." Bu alt problemdeki anlamlı ilişki tek soruda sınanmıştır.

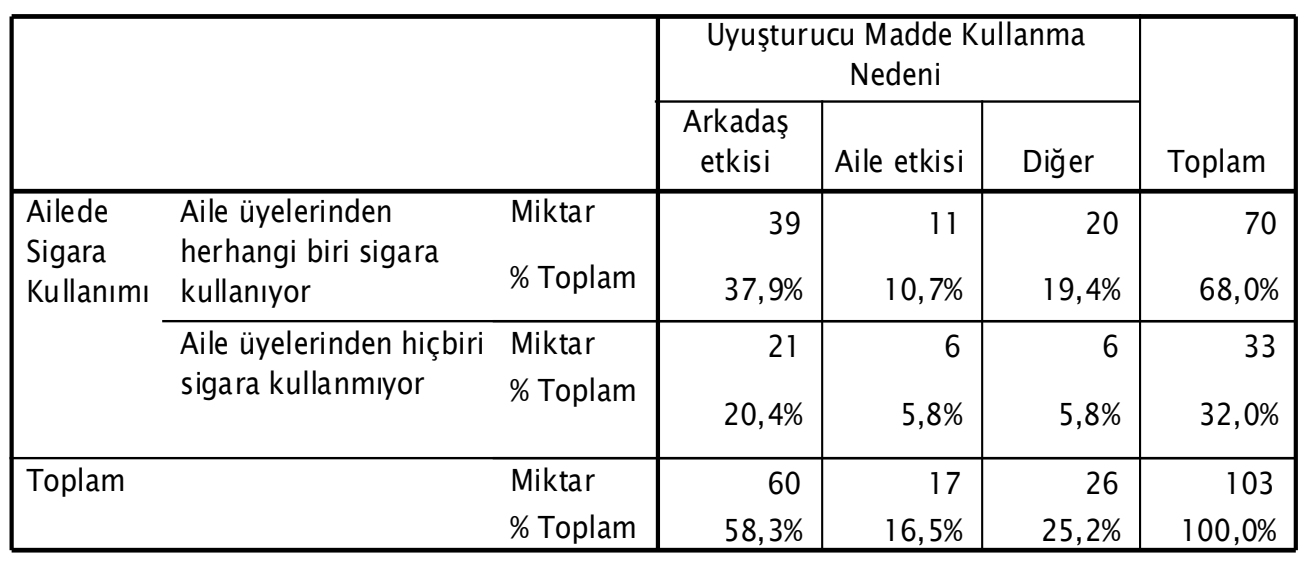

Tablo13: Ailede Sigara Kullanımı ile Madde Kullanma Nedeninin Sınanması

Tablo incelendiği zaman, ailede herhangi birinin sigara kullanım oranın \%68 olduğu görülür. Bu oran içindeki aile etkisiyle uyuşturucu madde kullanan bağımlıların oranı, \%10,7'dir. Yapılan analiz sonucu; $\alpha=0.05<p=0,526$ değerleri saptandığından, ailede sigara kullanımı ile 


\section{Murat Koçanlı}

gencin uyuşturucu madde kullanım nedeni arasında anlamlı bir ilişki olmadığı gözlemlenmiştir.

\subsection{3'üncü Alt Problemin Test Edilmesi}

"Ebeveynlerden birinin ya da her ikisinin uyuşturucu madde kullanması ile gencin uyuşturucu maddeye başlama nedeni arasında ilişki vardır.

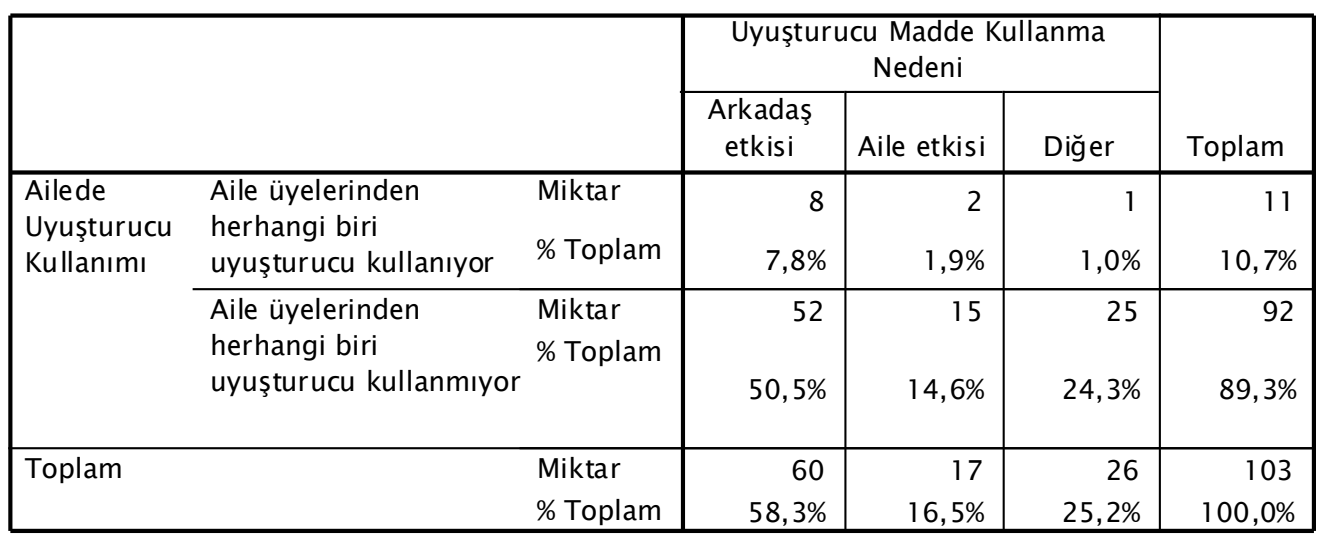

Tablo14: Ailede Uyuşturucu Kullanımı ile Madde Kullanma Nedeninin Sınanması

Ailede uyuşturucu madde kullanımının yüzde dağılımı incelendiğinde, bağımlıların sadece \%1,9'u aile etkisiyle uyuşturucu madde kullanımına başladıkları görülür. Araştırma grubunun arkadaş etkisiyle uyuşturucu madde kullanım oranın ise, $\% 7,8$ olduğu gözlemlenmiştir. Bu oranlar, ailede uyuşturucu madde kullanımının aile etkisinin fazla olmadığının bir göstergesidir.

Genel olarak incelendiğinde, sadece ailede alkol kullanımı ile gencin uyuşturucu madde kullanımı nedeni arasında anlamlı bir ilişki olduğu görülmüştür. Sigara ve uyuşturucu kullanımı ile gencin uyuşturucu madde kullanma nedeni arasında anlamlı bir ilişki bulunamamıştır.

\subsection{5 'inci Alt Hipotezin Test Edilmesi}

"Ebeveynlerden birinin ya da her ikisinin suç işleme durumu ile gencin uyuşturucu maddeye başlama nedeni arasında ilişki vardır." 


\begin{tabular}{|c|c|c|c|c|c|c|}
\hline & & & \multicolumn{3}{|c|}{$\begin{array}{l}\text { Uyuşturucu Madde Kullanma } \\
\text { Nedeni }\end{array}$} & \multirow[b]{2}{*}{ Toplam } \\
\hline & & & $\begin{array}{l}\text { Arkadaş } \\
\text { etkisi }\end{array}$ & Aile etkisi & Diğer & \\
\hline \multirow{4}{*}{$\begin{array}{l}\text { Ailede Suç } \\
\text { İşleme } \\
\text { Durumu }\end{array}$} & \multirow{2}{*}{$\begin{array}{l}\text { Aile üyelerinden } \\
\text { herhangi biri suç işlemiş }\end{array}$} & Miktar & $\overline{7}$ & 1 & 3 & 11 \\
\hline & & \% Toplam & $6,8 \%$ & $1,0 \%$ & $2,9 \%$ & $10,7 \%$ \\
\hline & \multirow{2}{*}{$\begin{array}{l}\text { Aile üyelerinden } \\
\text { herhangi biri suç } \\
\text { işlememiş }\end{array}$} & Miktar & 53 & 16 & 23 & 92 \\
\hline & & & $51,5 \%$ & $15,5 \%$ & $22,3 \%$ & $89,3 \%$ \\
\hline \multirow{2}{*}{ Toplam } & & Miktar & 60 & 17 & 26 & 103 \\
\hline & & \% Toplam & $58,3 \%$ & $16,5 \%$ & $25,2 \%$ & $100,0 \%$ \\
\hline
\end{tabular}

Tablo15: Ailede Sabıka Durumu ile Madde Kullanma Nedeninin Sınanması

Ailede suç işlemenin yüzde dağılımı incelendiğinde, bağımlıların sadece \%1'i aile etkisiyle uyuşturucu madde kullanımına başladıkları görülür. Bu oranın oldukça düşük çıkması, ailede suç işleme durumu ile gencin uyuşturucu madde kullanım nedeni arasında bir ilişki olmadığının bir göstergesi olabilir.

Araştırmanın 1'inci temel hipotezi analiz edildiğinde; anne-genç ilişkisi, anne ve genç arasındaki sorunlar, anne ve baba arasındaki Sayfa|604 geçimsizlik ve ailede alkol kullanımı ile gencin uyuşturucu madde kullanım nedeni arasında anlamlı bir ilişki olduğu gözlemlenmiştir. Diğer değişkenler ile gencin uyuşturucu madde kullanım nedeni arasında istatiksel olarak bir fark bulunamamıştır.

\subsection{2'nci Temel Hipotezin Test Edilmesi}

"Aile yapısı ile gençlerin uyuşturucu madde tedavisine karar verme nedeni arasında ilişki vardır."

2. temel hipotezin sınanması amacıyla üç adet alt hipotez oluşturulmuştur. Her bir alt hipotez kendi içerisinde değerlendirilmiştir.

"Aile içi iletişim ile gencin uyuşturucu madde tedavisine karar verme nedeni arasında ilişki vardır." Bu alt hipotez dört alt problem olarak değerlendirilmiştir.

\subsection{1'inci Alt Problemin Test Edilmesi}

"Baba ve gencin birbiriyle olan iletişimi ile gencin uyuşturucu madde tedavisine karar verme nedeni arasında ilişki vardır." Bu alt problemdeki anlamlı ilişki iki soruda sınanmıştır. 


\begin{tabular}{|c|c|c|c|c|c|}
\hline & \multicolumn{2}{|c|}{$\begin{array}{c}\text { Uyuşturucu Madde } \\
\text { Tedavisine Karar Verme }\end{array}$} & \\
\hline & & & Aileye İlişkin & $\begin{array}{c}\text { Daha } \\
\text { Düzenli } \\
\text { Yaşamayı }\end{array}$ & \\
\hline \multirow{3}{*}{$\begin{array}{l}\text { Baba-Genç } \\
\text { İliş̧isi }\end{array}$} & \multirow{2}{*}{$\begin{array}{l}\text { Demokratik } \\
\text { Baba }\end{array}$} & Miktar & 13 & 29 & 42 \\
\hline & & \% Toplam & $18.6 \%$ & $41.4 \%$ & $60.0 \%$ \\
\hline & $\begin{array}{l}\text { Otoriter veya } \\
\text { Umursamaz } \\
\text { Baba }\end{array}$ & $\begin{array}{r}\text { Miktar } \\
\% \text { Toplam }\end{array}$ & $\begin{array}{r}9 \\
12.9 \%\end{array}$ & $\begin{array}{r}19 \\
27.1 \%\end{array}$ & $\begin{array}{r}28 \\
40.0 \%\end{array}$ \\
\hline \multirow[t]{2}{*}{ Toplam } & & Miktar & 22 & 48 & 70 \\
\hline & & $\%$ Toplam & $31.4 \%$ & $68.6 \%$ & $100.0 \%$ \\
\hline
\end{tabular}

Tablo16: Baba-Genç İlişkisi ile Tedaviye Karar Vermenin Sınanması

Baba-genç ilişkisi ile gencin tedaviye karar verme nedeni incelendiğinde, babası ile ilişkisini demokratik olarak tanımlayan grubun \%18,6'sı aileye ilişkin nedenlerin etkisiyle uyuşturucu madde tedavisine karar verdikleri görülür. Fakat babasıyla ilişkisini otoriter veya umursamaz olarak tanımlayan bağımlıların aile etkisiyle uyuşturucu madde tedavisine karar verenlerin oranı, \%12,9 olduğu Sayfa| 605 tespit edilmiştir. Yapılan analiz sonucu, çapraz tablonun $2 * 2$ olması ve teorik frekanslardan birinin 8.80 çıkması nedeniyle Ki-Kare değeri olarak yates düzeltmesinin değeri dikkate alınmıştır. Tespit edilen değerler ise; $\alpha=0.05<p=1.000$ 'dir. Dolayısıyla baba-genç ilişkisi ile gencin uyuşturucu madde tedavisine karar verme nedeni arasında anlamlı bir ilişki gözlenememiştir.

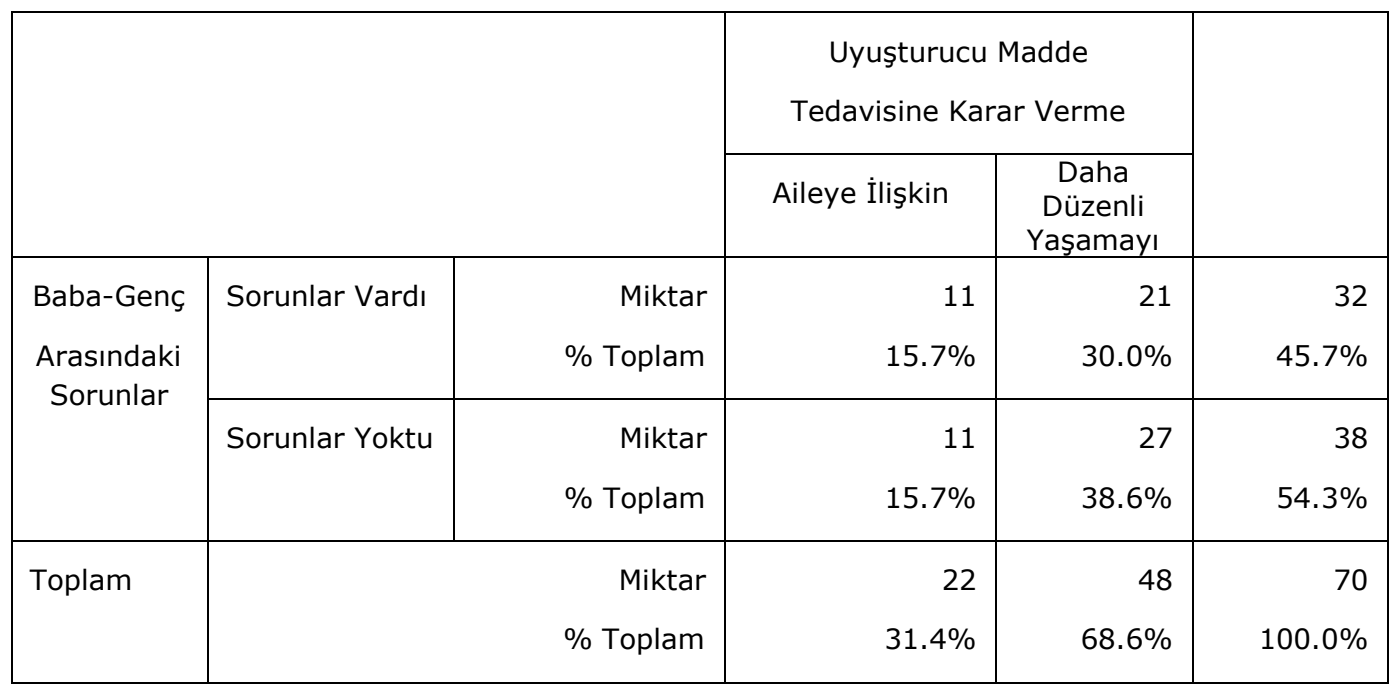

Tablo17: Baba ve Genç Arasındaki Sorunlar ile Madde Tedavisine 


\section{Murat Koçanlı}

Karar Verme Nedeninin Sınanması

Babalarıyla arasında herhangi bir sorun olduğunu belirten bağımlıların \%15,7'si aile ve \%30'u daha düzenli hayat yaşamayı isteme nedenlerinin etkisiyle uyuşturucu madde tedavisine karar vermişlerdir. Bununla birlikte babalarıyla arasında herhangi bir sorun olmadığını belirten bağımlıların aileye ilişkin nedenlerden ötürü uyuşturucu madde tedavisine karar verme oranının aynı olduğu gözlemlenmiştir. Yapılan analiz sonucu; $\alpha=0.05<p=0.626$ değerlerinin bulunması nedeniyle, baba ve genç arasındaki sorunların gencin uyuşturucu madde tedavisine karar verme nedeni üzerinde anlamlı bir etkisi olmadığı söylenebilir.

\subsection{2'nci Alt Problemin Test Edilmesi}

"Anne ve gencin birbiriyle olan iletişimi ile gencin uyuşturucu madde tedavisine karar verme nedeni arasında ilişki vardır." Bu alt problemdeki anlamlı ilişki iki soruda sınanmıştır.

\begin{tabular}{|c|c|c|c|c|c|}
\hline & & & \multicolumn{2}{|c|}{$\begin{array}{c}\text { Uyuşturucu Madde } \\
\text { Tedavisine Karar Verme }\end{array}$} & \\
\hline & & & Aileye İlişkin & $\begin{array}{c}\text { Daha } \\
\text { Düzenli } \\
\text { Yaşamayı }\end{array}$ & \\
\hline \multirow[t]{2}{*}{$\begin{array}{c}\text { Anne-Genç } \\
\text { İlişkisi }\end{array}$} & $\begin{array}{l}\text { Demokratik } \\
\text { Baba }\end{array}$ & $\begin{array}{l}\text { Miktar } \\
\% \text { Toplam }\end{array}$ & $\begin{array}{r}21 \\
23.3 \%\end{array}$ & $\begin{array}{r}43 \\
47.8 \%\end{array}$ & $\begin{array}{r}64 \\
71.1 \%\end{array}$ \\
\hline & $\begin{array}{l}\text { Otoriter veya } \\
\text { Umursamaz } \\
\text { Baba }\end{array}$ & $\begin{array}{l}\text { Miktar } \\
\text { \% Toplam }\end{array}$ & $\begin{array}{r}9 \\
10.0 \%\end{array}$ & $\begin{array}{r}17 \\
18.9 \%\end{array}$ & $\begin{array}{r}28 \\
28.9 \%\end{array}$ \\
\hline Toplam & & $\begin{array}{r}\text { Miktar } \\
\% \text { Toplam }\end{array}$ & $\begin{array}{r}30 \\
33.3 \%\end{array}$ & $\begin{array}{r}60 \\
66.7 \%\end{array}$ & $\begin{array}{r}90 \\
100.0 \%\end{array}$ \\
\hline
\end{tabular}

Tablo18: Anne-Genç İlişkisi ile Madde Tedavisine Karar Verme Nedeninin Sınanması

Tablo18 incelendiğinde, anneleriyle olan ilişkisini demokratik olarak tanımlayan grubun \%23,3'ü aileye ilişkin nedenlerden ötürü uyuşturucu madde tedavine karar verdikleri görülür. Bu oranın, anneleri ile ilişkisini otoriter veya umursamaz olarak nitelendiren bağımlıların aileye ilişkin nedenlerin etkisiyle uyuşturucu madde tedavisine karar verme oranı \%10'a düştüğü gözlemlenmiştir. Yapılan analiz sonucu, teorik frekanslardan birinin 8.67 ve $\alpha=0.05<p=1.000$ olduğu saptanmıştır. Bu nedenle anne-genç ilişkisi ile gencin 


\section{Murat Koçanlı}

uyuşturucu madde tedavisine karar verme nedeni arasında anlamlı bir ilişki tespit edilememiştir.

\begin{tabular}{|c|c|c|c|c|c|}
\hline & \multicolumn{2}{|c|}{$\begin{array}{c}\text { Uyuşturucu Madde } \\
\text { Tedavisine Karar Verme }\end{array}$} & \\
\hline & & & Aileye İlişkin & $\begin{array}{c}\text { Daha } \\
\text { Düzenli } \\
\text { Yaşamayı }\end{array}$ & \\
\hline \multirow{4}{*}{$\begin{array}{l}\text { Anne-Genç } \\
\text { Arasındaki } \\
\text { Sorunlar }\end{array}$} & \multirow[t]{2}{*}{ Sorunlar Vardı } & Miktar & 7 & 16 & 23 \\
\hline & & \% Toplam & $7.8 \%$ & $17.8 \%$ & $25.6 \%$ \\
\hline & \multirow[t]{2}{*}{ Sorunlar Yoktu } & Miktar & 23 & 44 & 67 \\
\hline & & $\%$ Toplam & $25.6 \%$ & $48.9 \%$ & $74.4 \%$ \\
\hline \multirow[t]{2}{*}{ Toplam } & & Miktar & 30 & 60 & 90 \\
\hline & & \% Toplam & $33.3 \%$ & $66.7 \%$ & $100.0 \%$ \\
\hline
\end{tabular}

Tablo19: Anne ve Genç Arasındaki Sorunlar ile Madde Tedavisine Karar Verme Nedeninin Sınanması

Annesi ile arasında herhangi bir sorun olan bağımlıların \% 7,8 'i aile ve $\% 17,8^{\prime} i$ daha düzenli bir hayat yaşamayı isteme nedenlerin etkisiyle madde tedavine karar vermişlerdir. Fakat bu oran, annesi ile arasında herhangi bir sorun olmayan bağımlılarda, \%25,6 ve \%48,9'a yükseldiği gözlemlenmiştir. Yapılan analiz sonucu, teorik frekanslardan birinin 7.67 çıktığı tespit edilmiştir. Dolayısıyla yates düzeltmesinin değeri dikkate alınarak $\alpha=0.05<p=0.932$ değerleri saptanmıştır. Bu değerler incelenince, anne ve genç arasındaki sorunlar ile gencin uyuşturucu madde tedavisine karar verme nedeni arasında istatiksel olarak bir fark olmadığı görülür.

\subsection{3'üncü Alt Problemin Test Edilmesi}

"Gencin kardeşleriyle olan iletişimi ile gencin uyuşturucu madde tedavisine karar verme nedeni arasında ilişki vardır." Bu alt problemdeki anlamlı ilişki tek soruda sınanmıştır.

\begin{tabular}{|c|r|r|r|r|r|}
\hline \multicolumn{2}{|c|}{} & \multicolumn{2}{c|}{$\begin{array}{c}\text { Uyuşturucu Madde } \\
\text { Tedavisine Karar Verme }\end{array}$} \\
\cline { 3 - 5 } & Aileye İlişkin & $\begin{array}{c}\text { Daha } \\
\text { Düzenli } \\
\text { Yaşamayı }\end{array}$ & \\
\hline $\begin{array}{c}\text { Kardeş- } \\
\text { Genç }\end{array}$ & İyi anlaşırdım & Miktar & 23 & 60 & 83 \\
& \% Toplam & $24.2 \%$ & $63.2 \%$ & $87.4 \%$ \\
\hline
\end{tabular}




\section{Murat Koçanlı}

\begin{tabular}{|c|l|r|r|r|r|}
\hline İlişkisi & $\begin{array}{l}\text { Hiç } \\
\text { anlaşamazdım }\end{array}$ & $\begin{array}{r}\text { Miktar } \\
\text { \% Toplam }\end{array}$ & 7 & 5 & 12 \\
& & $7.4 \%$ & $5.3 \%$ & $12.6 \%$ \\
\hline Toplam & & Miktar & 30 & 65 & 95 \\
& & \% Toplam & $31.6 \%$ & $68.4 \%$ & $100.0 \%$ \\
\hline
\end{tabular}

Tablo-20: Kardeş-Genç İlişkisi ile Tedaviye Karar Vermenin Sınanması

Tablo incelendiğinde, bağımlıların sadece \%7,4'ü aile etkisiyle uyuşturucu madde tedavisine karar verdikleri görülür. Fakat kardeşleriyle iyi anlaşan bağımlıların daha düzenli bir hayat yaşamayı isteme nedeninin etkisiyle madde tedavisine karar verme oranın \%63,2 olarak tespit edilmiştir. Yapılan analiz sonucu; $\alpha=0.1>p=0.072$ olduğundan, kardeş-genç ilişkisinin gencin madde tedavisine karar verme nedeni üzerinde etkili olduğu saptanmıştır. Bununla birlikte iki değişken arasındaki ilişkinin \%21,9 oranında olduğu gözlemlenmiştir.

\subsection{4'ncü Alt Problemin Test Edilmesi}

"Anne ve babanın birbiriyle olan iletişimi ile gencin uyuşturucu madde tedavisine karar verme nedeni arasında ilişki vardır." Bu alt problemdeki anlamlı ilişki üç soruda sınanmıştır.

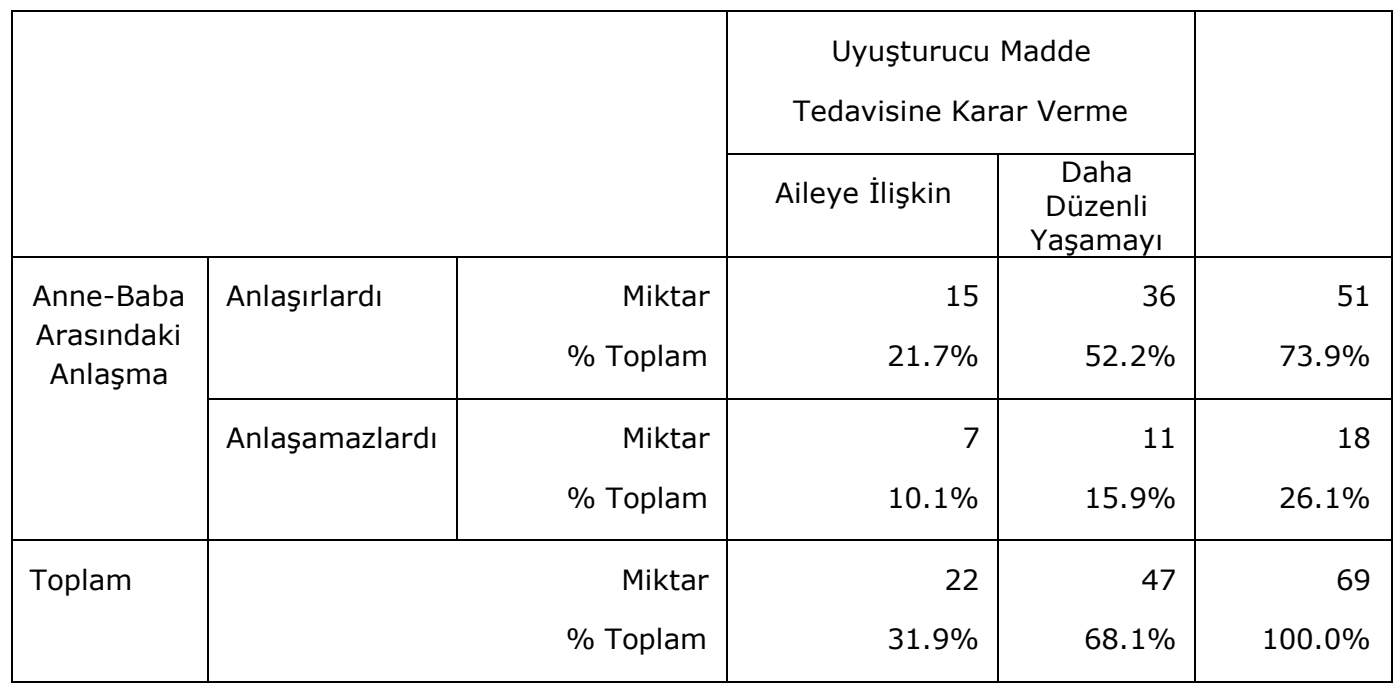

Sayfa | 608

Tablo21: Anne ve Baba Arasındaki Anlaşma ile Madde Tedavisine Karar Verme Nedeninin Sınanması

Anne ve babası arasında herhangi bir sorun olan grubun $\% 10,1^{\prime} \mathrm{i}$ aileye ilişkin nedenlerden ötürü madde tedavisi olmaya karar vermişlerdir. Bu oranın, diğer nedende \%15,9'a çıktığı tespit edilmiştir. Yapılan analiz sonucu; teorik frekanslardan birinin 5.74 ve $\alpha=0.05<p=0.654$ olduğu saptanmıştır. Bu sonuçlara dayanarak anne 


\section{Murat Koçanlı}

ve baba arasındaki anlaşma ile gencin uyuşturucu madde tedavisine karar verme nedeni arasında anlamlı bir ilişki olmadığı düşünülebilir.

\begin{tabular}{|c|c|c|c|c|c|}
\hline & & & $\begin{array}{l}\text { Uyuşturucu } \\
\text { Tedavisine Ka }\end{array}$ & $\begin{array}{l}\text { ladde } \\
\text { r Verme }\end{array}$ & \\
\hline & & & Aileye İlişkin & $\begin{array}{c}\text { Daha } \\
\text { Düzenli } \\
\text { Yaşamayı }\end{array}$ & \\
\hline Anne-Baba & Geçinirlerdi & Miktar & 14 & 26 & 40 \\
\hline $\begin{array}{l}\text { Arasındaki } \\
\text { Gecimsizlik }\end{array}$ & & \% Toplam & $20.3 \%$ & $37.7 \%$ & $58.0 \%$ \\
\hline & Geçinemezlerdi & Miktar & 8 & 21 & 29 \\
\hline & & \% Toplam & $11.6 \%$ & $30.4 \%$ & $42.0 \%$ \\
\hline Toplam & & Miktar & 22 & 47 & 69 \\
\hline & & \% Toplam & $31.9 \%$ & $68.1 \%$ & $100.0 \%$ \\
\hline
\end{tabular}

Tablo22: Anne ve Baba Arasındaki Geçimsizlik ile Madde Tedavisine Karar Verme Nedeninin Sınanması

Anne ve baba arasındaki geçimsizlik ile gencin uyuşturucu madde tedavisine karar verme nedeni analiz edildiğinde; teorik frekanslardan birinin 9.25 ve $\alpha=0.05<p=0.696$ olduğu tespit edilmiştir. Bu nedenle iki değişken arasında anlamlı bir ilişki olduğu gözlemlenememiştir.

\begin{tabular}{|c|c|c|c|c|c|}
\hline & \multicolumn{2}{|c|}{$\begin{array}{c}\text { Uyuşturucu Madde } \\
\text { Tedavisine Karar Verme }\end{array}$} & \\
\hline & & & Aileye İlişkin & $\begin{array}{c}\text { Daha } \\
\text { Düzenli } \\
\text { Yaşamayı } \\
\end{array}$ & \\
\hline \multirow{4}{*}{$\begin{array}{l}\text { Babanın } \\
\text { Anneye } \\
\text { Şiddet } \\
\text { Uygulaması }\end{array}$} & \multirow{2}{*}{ Uygulardı } & Miktar & 4 & 11 & 15 \\
\hline & & \% Toplam & $5.8 \%$ & $15.9 \%$ & $21.7 \%$ \\
\hline & \multirow[t]{2}{*}{ Uygulamazdı } & Miktar & 18 & 36 & 54 \\
\hline & & \% Toplam & $26.1 \%$ & $52.2 \%$ & $78.3 \%$ \\
\hline \multirow[t]{2}{*}{ Toplam } & & Miktar & 22 & 47 & 69 \\
\hline & & \% Toplam & $31.9 \%$ & $68.1 \%$ & $100.0 \%$ \\
\hline
\end{tabular}

Tablo23: Babanın Anneye Şiddet Uygulaması ile Madde Tedavisine Karar Verme Nedeninin Sınanması

Babanın anneye şiddet uygulamasının yüzde dağıııı incelendiğinde, bağımlıların sadece $\% 5,8$ 'i aile etkisiyle uyuşturucu madde tedavisine karar verdikleri görülür. Buna karşın şiddet uygulamayanların oranın \%78,3 olarak saptanması, bu değişkenin 


\section{Murat Koçanlı}

gencin madde tedavisine karar verme nedeni üzerinde bir etkisi olmadığı sonucu çıkartılabilir.

\subsection{2'nci Alt Hipotezin Test Edilmesi}

"Ebeveynlerinin yokluğu ve üveyliği ile gencin uyuşturucu madde tedavisine karar verme nedeni arasında ilişki vardır." Bu alt hipotez iki alt problem olarak değerlendirilmiştir.

\subsection{1'inci Alt Problemin Test Edilmesi}

"Ebeveynlerden birinin ya da her ikisinin yokluğu ile gencin uyuşturucu madde tedavisine karar verme nedeni arasında ilişki vardır." Bu alt problemdeki anlamlı ilişkinin varlığı tek soruda ölçülmüştür.

\begin{tabular}{|c|c|c|c|c|c|}
\hline & \multicolumn{2}{|c|}{$\begin{array}{c}\text { Uyuşturucu Madde } \\
\text { Tedavisine Karar Verme }\end{array}$} & \\
\hline & & & Aileye İlişkin & $\begin{array}{c}\text { Daha } \\
\text { Düzenli } \\
\text { Yaşamayı }\end{array}$ & \\
\hline \multirow[t]{2}{*}{$\begin{array}{l}\text { Anne-Baba } \\
\text { Yokluğu }\end{array}$} & $\begin{array}{lr}\text { Anne } & \text { ve } \\
\text { Babanın } & \text { İkisi } \\
\text { de Öz } & \end{array}$ & $\begin{array}{r}\text { Miktar } \\
\text { \% Toplam }\end{array}$ & $\begin{array}{r}23 \\
22.3 \%\end{array}$ & $\begin{array}{r}46 \\
44.7 \%\end{array}$ & $\begin{array}{r}69 \\
67.0 \%\end{array}$ \\
\hline & $\begin{array}{l}\text { Anne ve/veya } \\
\text { Babanın birisi } \\
\text { ya da İkisi de } \\
\text { Sağ Değil }\end{array}$ & $\begin{array}{l}\text { Miktar } \\
\% \text { Toplam }\end{array}$ & $\begin{array}{r}9 \\
8.7 \%\end{array}$ & $\begin{array}{r}25 \\
24.3 \%\end{array}$ & $\begin{array}{r}34 \\
33.0 \%\end{array}$ \\
\hline Toplam & & $\begin{array}{r}\text { Miktar } \\
\text { \% Toplam }\end{array}$ & $\begin{array}{r}32 \\
31.1 \%\end{array}$ & $\begin{array}{r}71 \\
68.9 \%\end{array}$ & $\begin{array}{r}103 \\
100.0 \%\end{array}$ \\
\hline
\end{tabular}

Tablo24: Anne-Baba Yokluğu ile Tedaviye Karar Vermenin Sınanması

Anne ve/veya babası ya da her ikisi de sağ olmayan araştırma grubunun \%8,7'si aileye ilişkin nedenlerden dolayı madde tedavisi olmaya karar vermişlerdir. İki değişken analiz edildiğinde; $\alpha=0.05<p=0.479$ değerlerinin tespit edilmesinden dolayı iki değişken arasında anlamlı bir ilişki olmadığı sonucu çıkartılabilir.

\subsection{2'nci Alt Problemin Test Edilmesi}

"Ebeveynlerden birinin ya da her ikisinin üvey olması ile gencin uyuşturucu madde tedavisine karar verme nedeni arasında ilişki vardır." Bu alt problemdeki anlamlı ilişkinin varlığı tek soruda ölçülmüştür. 


\begin{tabular}{|c|c|c|c|c|c|}
\hline & \multicolumn{2}{|c|}{$\begin{array}{c}\text { Uyuşturucu Madde } \\
\text { Tedavisine Karar Verme }\end{array}$} & \\
\hline & & & Aileye İliş̧kin & $\begin{array}{c}\text { Daha } \\
\text { Düzenli } \\
\text { Yaşamayı }\end{array}$ & \\
\hline \multirow[t]{2}{*}{$\begin{array}{l}\text { Anne-Baba } \\
\text { Üveyliği }\end{array}$} & $\begin{array}{lr}\text { Anne } & \text { ve } \\
\text { Babanın } & \text { İkisi } \\
\text { de Öz } & \end{array}$ & $\begin{array}{l}\text { Miktar } \\
\text { \% Toplam }\end{array}$ & $\begin{array}{r}29 \\
28.2 \%\end{array}$ & $\begin{array}{r}68 \\
66.0 \%\end{array}$ & $\begin{array}{r}97 \\
94.2 \%\end{array}$ \\
\hline & $\begin{array}{l}\text { Anne ve/veya } \\
\text { Babanın birisi } \\
\text { ya da İkisi de } \\
\text { Üvey }\end{array}$ & $\begin{array}{l}\text { Miktar } \\
\% \text { Toplam }\end{array}$ & $\begin{array}{r}3 \\
2.9 \%\end{array}$ & $\begin{array}{r}3 \\
2.9 \%\end{array}$ & $\begin{array}{r}6 \\
5.8 \%\end{array}$ \\
\hline Toplam & & $\begin{array}{r}\text { Miktar } \\
\text { \% Toplam }\end{array}$ & $\begin{array}{r}32 \\
31.1 \%\end{array}$ & $\begin{array}{r}71 \\
68.9 \%\end{array}$ & $\begin{array}{r}103 \\
100.0 \%\end{array}$ \\
\hline
\end{tabular}

Tablo25: Anne-Baba Üveyliği ile Tedaviye Karar Vermenin Sınanması

Yapılan analiz sonucu, gözelerdeki 5'ten küçük iki gözün teorik değeri \%50 olarak tespit edildiğinden, anne-baba üveyliğinin yüzde dağılımı incelendiğinde, bağımlıların sadece \%2,9'u aile etkisiyle uyuşturucu madde tedavisine karar verdikleri görülür. Diğer taraftan anne ve babası öz olan bağımlıların \%94,2'si madde tedavisi olmaya Sayfa | 611 karar vermişlerdir. Bu oran oldukça yüksektir. Dolayısıyla anne-baba üveyliğinin gencin madde tedavi kararı üzerinde belirgin bir etkisi yoktur.

\subsection{3'üncü Alt Hipotezin Test Edilmesi}

"Ailenin aylık gelir düzeyi ile gencin uyuşturucu madde tedavisine karar verme nedeni arasında ilişki vardır." Bu alt hipotez tek alt problem olarak değerlendirilmiştir.

\begin{tabular}{|c|c|c|c|c|c|}
\hline & & & \multicolumn{2}{|c|}{$\begin{array}{c}\text { Uyuşturucu Madde } \\
\text { Tedavisine Karar Verme }\end{array}$} & \\
\hline & & & Aileye İlişkin & $\begin{array}{c}\text { Daha } \\
\text { Düzenli } \\
\text { Yaşamayı }\end{array}$ & \\
\hline \multirow{6}{*}{$\begin{array}{l}\text { Ailenin } \\
\text { Gelir } \\
\text { Düzeyi }\end{array}$} & \multirow[t]{2}{*}{ Asgari Ücret } & Miktar & 5 & 18 & 23 \\
\hline & & \% Toplam & $4.9 \%$ & $17.5 \%$ & $22.3 \%$ \\
\hline & \multirow{2}{*}{$\begin{array}{l}\text { 319-999 } \\
\text { Milyon }\end{array}$} & Miktar & 10 & 25 & 35 \\
\hline & & \% Toplam & $9.7 \%$ & $24.3 \%$ & $34.0 \%$ \\
\hline & \multirow{2}{*}{$\begin{array}{l}1 \text { Milyar ve } \\
\text { Üstü }\end{array}$} & Miktar & 17 & 28 & 45 \\
\hline & & $\%$ Toplam & $16.5 \%$ & $27.2 \%$ & $43.7 \%$ \\
\hline
\end{tabular}




\begin{tabular}{|l|r|r|r|r|}
\hline Toplam & Miktar & 32 & 71 & 103 \\
& $\%$ Toplam & $31.1 \%$ & $68.9 \%$ & $100.0 \%$ \\
\hline
\end{tabular}

Tablo26: Aile Gelir Düzeyi ile Tedaviye Karar Vermenin Sınanması

Ailenin gelir düzeyi ile gencin tedavi kararı incelendiğinde, araştırma grubun \%31,1'i aileye ilişkin nedenlerin etkisiyle madde tedavi olmaya karar vermişlerdir. Bu oran içinde, aylık gelir ortalamaları 1 milyar ve üstü olan bağımlıların oranın \%16,5 çıktığı gözlemlenmiştir. İki değişken analize tabi tutulduğunda; $\alpha=0.05<p=0.371$ değerlerinin çıkması iki değişken arasında istatiksel olarak bir fark olmadığı sonucu çıkartılabilir.

2'nci temel hipotez analiz edildiğinde; aile içi ilişkiler, anne-baba yokluğu, üveyliği ve gelir seviyesi ile gencin uyuşturucu madde tedavisine karar verme nedeni arasında anlamlı bir ilişki olmadığı gözlemlenmiştir. Sadece kardeş-genç arasındaki ilişkinin gencin uyuşturucu madde tedavi kararında \%21,9 oranında etkili olduğu tespit edilmiştir.

Günümüzde uyuşturucu madde kullanım nedenleri olarak tek bir neden gösterilmemektedir. Uyuşturucu madde kullanımı birçok Sayfa|612 davranışın bileşkesi olarak kabul edilmektedir (İçli, 2001). Araştırma grubu, uyuşturucu madde kullanım nedeni olarak \%58 oranında arkadaş çevresi ve \%17 oranında aile etkisini görmektedir. Bu sonuçlar Emniyet Genel Müdürlüğü ve Jandarma Genel Komutanlığının (2002 ve 2003) yasal işlem yaptığı uyuşturucu madde bağımlılarına uyguladığı anket sonuçları benzerlikler göstermektedir.

Genel olarak uyuşturucu madde kullanım nedeni incelendiğinde birçok değişkenin etkili olduğu görülür. Fakat önemli olan, tek bir değişkenin tek başına etkili olamayacağıdır. Bu araştırmada, gençlerin uyuşturucu madde kullanımında aile içi ilişkilerin önemli bir yere sahip olduğu gözlemlenmiştir. Özellikle anne-genç ilişkisinin niteliği gençlerin uyuşturucu madde kullanımında istatiksel olarak bir fark olduğu tespit edilmiştir. Bununla birlikte anne ve babanın birbirleriyle geçinememesi, başka bir deyişle aralarındaki sorunlarını aile ortamına yansıtmaları bireyleri uyuşturucu madde kullanımına ittiği saptanmıştır. Ailede var olan alkol kullanımı da gençlerin uyuşturucu madde kullanımına neden olduğu görülmüştür. Diğer yandan kardeş-genç ilişkisi ile gencin madde tedavi kararında etkili olduğu gözlemlenmiştir. Tüm bu değişkenler, aile içindeki ilişkilerin uyuşturucu madde kullanımında ne denli önemli 
olduğunun bir göstergesi olarak düşünülebilir. Bu nedenle gençlerin uyuşturucu madde kullanımı ve tedavi sürecinde aile içi ilişkilerin niteliğinin sağlam bir zemine oturtulması çok önemlidir.

\section{SONUÇ}

Araştırma sonuçları genel olarak değerlendirildiğinde öncellikle sosyalizasyon sürecinin ilk basamağı ve toplumun en temel grubu olarak kabul edilen aile kurumuna çok önemli görevler düştüğü söylenebilir. Devletten önce aile içerisinde aile üyeleri arasındaki birbirine bağlılıkları kuvvetlendirilmelidir. Bu bağı kuvvetlendirmek için anne ve babalara çok önemli görevler düşmektedir.

- En başta anne ve baba, çocuklara tüm davranışlarıyla örnek olmalıdır. Özellikle anne-babalar çocuklarının yanında ya da hiçbir zaman herhangi bir madde kullanmayarak örnek bir model oluşturmalıdır. Çocuklar sosyal öğrenme kuramı çerçevesinde ebeveynlerin davranışlarını gözlemleyip kendilerine model olarak algılarlar.

- Anne-babalar aile içi kuralları koyan ve ailenin alkol ve madde konusunda politikasını belirleyen kişilerdir. Dolayısıyla bu konuda bazı kısıtlamalar getirmeleri ve bunları uygulamaları gerekmektedir. Zira ailede alkol ve madde kullanımı, çocukların bu maddeleri kullanım riskini yükselttiği bu çalışmada tespit edilmiştir.

- Anne-babalar çocuklarının arkadaş baskısı ile nasıl başa çıkabilecekleri konusunda bilgilendirmeli ve eğitmelidir.

- Anne-babalar çocuklarının aile ortamının dışındayken nerede bulunduklarını bilmelidir. Gerekirse takip etmelidir.

- Anne-babalar diğer aileler ile iş birliği yaparak çocukların madde kullanmasını engellemelidir.

- Anne-babalar madde kullanımını hisseden kişiler olmalıdır. Çocuklarının madde kullanımını takip etmelidir. Belirtileri hakkında bilgi sahibi olmalıdırlar.

- Anne-babalar çocuğun madde kullanımına müdahale eden ve yönlendiren kişilerdir. Uyuşturucu madde kullanımında erken teşhis çok önemlidir. Bu nedenle tedavi sürecinin bir an önce başlatılması gerekir. Tedavi sürecinde de aileler çocuklarına sürekli destek olmalıdır. Zira tedavi sürecinde ailenin önemi çok büyüktür. 
- Diğer yandan ailelerin yanında gençlere de önemli görevler düşmektedir. Nitekim bu ilişki karşılıklıdır. Gençler de ailelerine bağlarını kuvvetlendirmek amacıyla kendi üzerine düşen sorumluluklarını yerine getirmelidir.

- Sevgi ve huzurun arkadaş gruplarında değil bizzat aile içinde olduğunun unutulmaması gerekir.

- Sapkın arkadaş guruplarından uzak durulması gerekir. Çünkü her türlü olumsuz veya zararlı sonuçlar bu tür arkadaş gruplarından gelir. Zira kötü arkadaş gruplarında var olan sapmış davranışlar, uyuşturucu madde kullanım riskini yükseltebilir.

- Uyuşturucu kültürünün yoğun olduğu birahane, diskotek, kahvehane, kumarhane, meyhane ve benzeri yerlerden uzak durulmalıdır.

Bununla birlikte uyuşturucu madde kullanım yaygınlığının önlenmesinde devlete önemli görevler düşmektedir. Uyuşturucu madde bağımlıı̆ında özellikle Milli Eğitim, Sağlık ve İçişleri Bakanlıklarının önemli sorumlulukları vardır. Bu çalışmanın esası, jandarmanın etkinliğine dayandığından Jandarma Genel Komutanlığının etkinliğinin artıracak önlemler üzerinde durulacaktır.

Aslında Jandarma Genel Komutanlığı kendi görev ve sorumluluk sahasında, ilgili yasalar çerçevesinde uyuşturucu madde bağımlılığından çok uyuşturucu madde kaçakçılığı ile mücadele etmektedir. Nitekim uyuşturucu madde kaçakçılığı ile mücadele etmek bir anlamda madde bağımlıığı ile mücadele anlamı taşımaktadır. Fakat Jandarma Genel Komutanlığının görev ve sorumluluk sahası, genel olarak kent merkezi dışındadır. Buna rağmen özellikle İstanbul, Ankara ve İzmir gibi büyük kent merkezlerinde kendisine önemli sorumluluk ve görevler verilmiştir. Bu tür kent merkezlerinde Jandarma Genel Komutanlığının sorumluluk sahasının olması, uyuşturucu madde bağımlıı̆ı ile daha iyi mücadele etmesini gerektirir.

Jandarma Genel Komutanlığı da Emniyet Genel Müdürlüğü gibi teşkilatlanmıştır. Başka bir ifadeyle, her il merkezinde KOM şube, bazı ilçe merkezlerinde ise KOM kısımları teşkil edilmiştir. Fakat bu şube ve kısımlar daha çok uyuşturucu madde kaçakçılığı ile ilgili görevleri icra etmektedirler. Uyuşturucu madde bağımlılığı ile mücadelenin etkinliğini artırmak için Jandarma Genel Komutanlığının aşağıdaki önlemleri alması gerektiği değerlendirilmektedir: 


\section{Murat Koçanlı}

- Önleyici kolluk hizmetleri esnasında ailelere uyuşturucu madde bağımlıığının zararları anlatılmalı ve bilgi broşürleri dağıtılmalıdır.

- Uyuşturucu madde kullanımının yoğun olduğu merkezlerde uzman personel takviyesi yapılmalıdır. Personelin Birleşmiş Milletler ve Avrupa Birliği nezdinde açılan kurslara gönderilmesi sağlanmalıdır.

- Gerek özel gerekse resmî kurumlar ile işbirliğine gidilmesi ve ortak bir mücadele planın oluşturulması gerekir.

- Jandarma Çocuk Merkezlerinin aktivesinin artırılması sağlanmalıdır.

- Önleyici kolluk hizmetlerin planlamasında, uyuşturucu madde satıcılarının yoğun olduğu yerlerde yapılması, mücadelede alınabilecek önemli tedbirlerden biridir. Zira bu merkezlerde uyuşturucu madde satışının önlenmesi, bağımlı miktarının azaltılmasında çok önemlidir.

- İlçe Jandarma Komutanlığının sorumluluk sahasında bulunan okullarla sürekli irtibat içinde olunmalıdır. Okul yöneticilerin de en ufak bir şüphede İlçe Jandarma Komutanlığına bilgi vermesi gerekir.

- İlçe Jandarma Komutanlığı, kendi sorumluluk sahasında bulunan bar, disko, kafe gibi yerlere daha sık önleyici kolluk hizmeti planlamalı ve uygulamalıdır.

- İlçe Jandarma Komutanlığı, yasal işlem yaptığı uyuşturucu madde bağımlılarına olumlu bir tarzda yaklaşmalı ve tedavi sürecinin öneminden bahsetmelidir.

- Bununla birlikte kurum içinde ve dışında uyuşturucu madde bağımlılığı ile ilgili olarak bilimsel araştırmaların yapılması ve sonuçlarının tüm kurum genelinde uygulanması gerekir.

Sonuç olarak uyuşturucu madde bağımlılığı ile mücadele, kurumlar arası koordinasyonu gerektiren bir konudur. Tüm kurumlar mevcut imkanlarını kullanarak mücadeleye olumlu katkılarda bulunması gerekir. Jandarma Genel Komutanlığının etkinliğinin artırılması amacıyla önerilen tavsiyelerin uygulamasının mücadelede alınabilecek en önemli tedbirlerden olacağı kıymetlendirilmektedir. 


\section{KAYNAKÇA}

Akers, R. (1999). Criminological Theories: Introduction and Evaluation ( $2^{\text {nd }}$ edition). Chicago: Fitzroy Dearborn Publishers.

Amaro, H. (1995). Love, Sex, and Power. American Psychologist 50(6), 437-447.

Arman, T. (1993). Uçucu Madde Bağımlılarının Sosyo-Demografik Özelliklerinin ve Ailelerinin Çocuk Yetiştirme Tutumlarının İncelenmesi. (Yayımlanmamış Yüksek Lisans Tezi). Marmara Üniversitesi Eğitim Bilimleri Fakültesi, İstanbul.

Bachman, J. G., Johnston, L. D. \& O'Malley, P. M. (1981). Monitoring the Future: Questionnaire responses from the nation's high school seniors, 1980. (pp. 265). Ann Arbor, MI: Institute for Social Research. Bahr, J., Marcos, C. \& Maughan, L. (1995). Family, Educational and Peer Influences on the Alcohol Use of Female and Male Adolescents. Journal of Studies on Alcohol 56, 457-469.

Baumrind, D. (1991). The Influence of Parenting Style on Adolescent Competence and Substance Use. Journal of Early Adolescence 11, 5695.

Burcu, E. (2002). Alcohol and Drug Use in Young Apprentices: Effect of Sayfa | 616 Social Control in the Family. Journal of Youth Adolescence 32(4), 291299.

Brook, J., Whiteman, M., Gordon, S. \& Brook, D. W. (1984). Paternal Determinants of Female Adolescents Marijuana Use. Developmental Psychology 20, 1032-1043.

Brook, J., Brook, W., Gordon, S., Whiteman, M. \& Cohen, P. (1990). The Psychosocial Etiology of Adolescent Drug Use: A Family Interactional Approach. Genetic, Social and General Psychology Monographs 116, 111-267.

Cairns, R. B., Leung, M. C., \& Cairns, B. D. (1995). Social Networks Over time and Space in Adolescence. In L. J. Crockett \& A. C. Crouter (Ed.). Pathways through adolescence: Individual Development in Relation to Social Contexts. The Penn State Series on Child and Adolescent Development (pp. 35-56). Hillsdale, NJ: Erlbaum.

Califano, J. (1990). Poor Child-Father Relationship is Major Factor in Teen Drug Use. New York: Guilford Press. 
Capaldi, D. \& Clark, S. (1997). Prospective Family Predictors of Aggression Toward Female Partners for at-Risk. Developmental Psychology 34, 1175-1188.

Challier, B. (2000). Associations of Family Environment and Individual Factors with Tobacco, Alcohol and Illicit Drug Use in Adolescents. European Journal of Epidemilogy 16, 33-42.

Coleman, J. S. (1988). Social Capital in the Creation of Human Capital. American Journal of Sociology 94, 94-120.

Çakıcı, M. (1997). Kuzey Kıbrıs Türk Cumhuriyeti Lise Gençliğinde Psiko Aktif Madde Kullanımının Yaygınlığı. (Yayımlanmamış Doktora Tezi). Yakındoğu Üniversitesi Psikoloji Bölümü, Lefkoşa.

Downey, D. B. (1995). Understanding Academic Achievement Among Children in Step Households: The Role of Parental Resources, Sex of Stepparent and Sex of Child. Social Forces 73, 875-894.

Emcdda. (2002). National Prevalence Estimates of Problem Drug Use in the European Union. 2002 EMCDDA Project Final Report I, Results.

Faupel, C. (1991). Shooting Dope: Career Patterns of Hard-Core Heroin Users. Gainesville: University of Florida Press.

Gold, M. (1993). Drugs of Abuse. A Comprehensive Series for Clinicians. New York: Plenum Publishing.

Gottfredson, M. \& Hirschi, T. (1990). A General Theory of Crime. Stanford/California: Stanford University Press.

Hirschi, T. (1969). Causes of Delinquency. Berkeley: University of California Press.

Hoffman, J. \& Johnson, R. J. (1998). A National Portrait of Family Structure and Adolescent Drug Use. Journal of Marriage and the Family $60,633$.

Hoffmann, J. \& Su, S. (1998). Parental Substance Use Disorder, Mediating Variables and Adolescent Drug Use: A Non-Recursive Model. Addiction 93, 1351.

Hoffman, J. \& Johnson, R. J. (2002). The Community Context of Family Structure and Adolescent Drug Use. Minneapolis 64, 314.

Huba, G. (1980). Longitudinal Analysis of the Role of Peer Support, Adult Models and Peer Subcultures in Beginning Adolescents Drug Use. Multivariate Behavioral Research 15, 259-280.

İçli, T. (2001). Kriminoloji. Ankara: Semih Ofset Matbaacılık ve Yayıncilık. 
İstanbul Emniyet Müdürlüğü. (1999). Uyuşturucu Madde Kaçakçılığı ve Bağımlılık Açısından Uyuşturucu Sorunu. İstanbul: Barış Yayınevi.

Jessor, R. \& Jessor, S. L. (1977). Problem Behavior and Psychological Development. New York: Academic Press.

Kandel, D. B. \& Wu, P. (1995). The Contributions of Mothers and Fathers to the Intergenerational Transmission of Cigarette Smoking in Adolescence. Journal of Research of Adolescents 5, 225-252.

Katz, S., Duncan, R. \& Zimmerman, A. (1997). Adolescence Family Structure Versus Parental Attachment in Controlling Adolescent Deviant Behavior: A Social Control Model. Adolescence 32(125), 199215.

Kelly, J. (2002). Parent-Child Communication, Perceived Sanctions Against Drugs Use and Youth Drug Involvement Adolescence. Roslyn Heights 37, 775.

Krohn, M., Lizotte J. \& Perez, C. (1997). Early Substance Use and School Achievement: An Examination of Latino, White and African American Youth. Journal of Drug Issues 32, 921.

Lamborn, S. (1991). Pattern of Competence and Adjustment Among Adolescents from Authoritative, Authoritarian, Indulgent and Neglectful Sayfa | 618 Families. Child Development 62, 1049-1065.

Merikangas, K. R., Stolar M. \& Rounsaville, B. J. (1998). Familial Transmission of Substance Use Disorders. Arch Gen Psychiatry 55, 973-979.

Miller, K. (2003). Early Drug Use Associated with Later Mental Disorder. American Family Physician 67, 1354.

Newcomb, M. D. \& Rickards, S. (1995). Parent Drug-Use Problems and Adult Intimate Relations: Associations Among Community Samples of Young Adult Women and Men. Journal of Counseling Psychology 42, 141-152.

Ögel, K. \& Tamar, D. (1996). Uyuşturucu Maddeler ve Bağımlılık. Okul Eğitim Paketi. AMATEM / Özel Okullar Derneği Gençlik Anketi.

Ögel, K. (1997). Uyuşturucu Maddeler ve Bağımlılık. İstanbul: İletişim Yayınları.

Patterson, G. R., Reid J. B. \& Dishion, T. J. (1992). Antisocial Boys. Eugene: Castalia.

Sampson, R. J. \& Laub, J. H. (1993). Crime in the Making: Pathways and Turning Points Through Life. Cambridge: Harvard University Press. 
Selnow, G. (1987). Parent-Child Relationships and Single and Two Parent Families: Implications for Substance Usage. Journal of Drug Education 17, 315-326

Sowder, B. J. \& Burt, M. R. (1980). Children of Heroin Addicts: An Assessment of Health. Learning, Behavioral and Adjustment Problems. New York: Praeger.

Steinberg, L., Dornbusch, S. M. \& Brown, B. B. (1992). Ethnic Differences in Adolescent Achievement: An Ecological Perspective American Psychology 47, 723-729.

Thomas, G. \& Farrell, M. (1996). The Effects of Single-Mother Families and Nonresident Fathers on Delinquency and Substance Abuse in Black and White Adolescents. Journal of Marriage and The Family 58, 884.

Thornberry, T. P. (1987). Towards an Interactional Theory of Delinquency. Criminology 25, 863-892.

UNODC. (2002). World Drug Report 2, Statistics.

Van Der Bree, M. (1998). Genetic and Environmental Influences on Drug Use and Abuse / Dependence in Male and Female Twins. Drug Alcohol Depend 52, 231-242.

Wade, J. \& Brannigan, A. (1996). The Genesis of Adolescent RiskTaking: Pathways Through Family, School and Peers. Canadian Journal of Sociology 23, 1-19.

Yavuzer, H. (1982). Çocuk ve Suç. İstanbul: İstanbul Üniversitesi Edebiyat Fakültesi Yayınları.

Yazman, Ü. (1995). Lise Gençliğinin Psiko Aktif Maddelere Bakış ve Kullanım Oranlarının Türkiye ve İstanbul Örneği ile İncelenmesi. (Yayımlanmamış Tıpta Uzmanlık Tezi). Bakırköy Ruh ve Sinir Hastalıkları Hastanesi, İstanbul.

Zakharov, I. A. (2001). Adolescents of the Risk Group. Russian Education and Society 43(11), 39-45.

Zuckerman, B. \& K. Bresnahn. (1991). Developmental and Behavioral Consequences of Prenatal Drug and Alcohol Exposure. Pediatric Clinics of North America 38, 1387-1406. 